\title{
Effects of Anxiolytic Drugs in Animal Models of Multiple Sclerosis
}

\author{
Silvia Novío, Manuel Freire-Garabal and María Jesús Núñez-Iglesias \\ Lennart Levi Stress and Neuroimmunology Laboratory, \\ University of Santiago de Compostela \\ Spain
}

\section{Introduction}

Multiple sclerosis (MS) is a chronic inflammatory demyelinating and neurodegenerative disease of the central nervous system (CNS), affecting more than 2 million people worldwide (Hirtz et al., 2007; McQualter \& Bernard, 2007; Sospedra \& Martin, 2005). Although it has been described for over two hundred years, it is not well characterized and no cure exists (Hirtz et al., 2007; McQualter \& Bernard, 2007). For this reason, nowadays there is still considerable interest in the investigation of the pathogenesis of this disease, the improvement of diagnosis, the assessment of prognosis, and the discovery of new therapeutic agents.

The CNS cannot easily be sampled, so to gain ideas about neuroinflammatory diseases, animal models are developed. Experimental research has been performed in many species, including monkeys (Genain \& Hauser, 2001), however most of the studies use rodents, fundamentally mice (Campbell et al., 2001; Chandler et al., 2002; Dowdell et al., 1999; Johnson et al., 2004, 2006; Meagher et al., 2007; Mi et al., 2004, 2006; Sieve et al., 2004, 2006; Steelman et al., 2009, 2010; Welsh et al., 2004; Whitacre et al., 1998; Young et al., 2008, 2010) and rats (Anane et al., 2003; Bukilica et al., 1991; Correa et al., 1998; Dimitrijević et al., 1994; Griffin et al., 1993; Kuroda et al., 1994; Laban et al., 1995a, 1995b; Le Page et al., 1994, 1996; Levine et al., 1962; Núñez-Iglesias et al., 2010; Owhashi et al., 1997; Pérez-Nievas et al., 2010; Teunis et al., 2002; Whitacre et al., 1998). In these studies, similar clinical phenotypes are achieved via different routes, so it is probable that some heterogeneity exists in the pathways leading to MS. In general, the standard experimental models of MS include: myelin mutant models, toxic demyelination models, viral models, and autoimmune models, being the virus-induced and immune-mediated models the most common ones for MS.

a. Myelin mutant models. Myelin mutants, such as the taiep rat and the Shiverer mouse (myelin basic protein (MBP) mutant), as well as gene knockout animals (e.g. myelin associated glycoprotein (MAG) knockout mouse) show axonal degeneration, altered neurotransmission, and in some instances clinical disease (Loers et al., 2004). Myelin mutant models have largely been used to study mechanisms of demyelination and remyelination. However, their relatively high cost has limited their widespread application (e.g. as preclinical drug screening tools). 
b. Toxic demyelination models. Neurotoxicants such as lysolecithin, ethidium bromide or cuprizone are used to induce chemical lesions. In lysolecithin and ethidium bromide models, a focal lesion is induced by stereotactic injection of the compound into the rodent CNS. The toxic effect of lysolecithin is considered to be selective on myelin producing cells while ethidium bromide is toxic for all nucleolus containing cells (Woodruff \& Franklin, 1999). The cuprizone model is widely used to study toxin induced demyelination. In this model, animals are fed with the copper chelator cuprizone (bis-cyclohexanone oxaldihydrazone) leading to demyelination, which is reversed after cessation of the toxin. This model is reliable and has the advantage of good reproducibility regarding the amount and site of demyelination (Matsushima \& Morell, 2001).

c. Viral models. Several viruses, including Semliki Forest Virus and Theiler's Murine Encephalomyelitis Virus (TMEV), induce disease by neurotrophic infection of the CNS, specifically oligodendrocytes. Succinctly, virally-infected cells are attacked by T cells inducing important humoral responses, which finally lead to demyelination (Ercolini \& Miller, 2006; Lavi \& Constantinescu, 2005). The Picornavirus TMEV is a naturally occurring pathogen that was originally isolated from mice. In this species, strains of Theiler's virus (BeAn, DA, WW, Yale) cause a biphasic disease that includes an acute CNS inflammatory phase followed by a chronic neuroinflammatory/autoimmune demyelination phase with glial and microglial infection (Oleszak et al., 2004). The chronic phase of the disease has many similarities, both behaviorally and physiologically with progressive MS (Dal Canto et al., 1995; Lipton, 1975; Oleszak et al., 2004; Tsunoda \& Fujinami, 1996), so Theiler's virus-induced demyelination (TVID) is commonly used as an excellent animal model of MS (Dal Canto et al., 1995; Oleszak et al., 2004; Tsunoda \& Fujinami, 1996) for studying: the pathogenesis, the disease susceptibility factors, the mechanisms of viral persistence within the CNS, and the mechanisms of virus-induced autoimmune disease (Welsh et al., 2009).

d. Autoimmune models. Experimental autoimmune encephalomyelitis (EAE) has received the most attention as a model of MS. Clinical and histological features of MS can be actively or passively induced. Active EAE is accomplished through inoculation with spinal cord homogenate or with many different CNS proteins or peptides (such as myelin oligodendrocyte glycoprotein (MOG), myelin-associated oligodendrocyte basic protein (MOBP), oligodendrocyte-specific protein (OSP), proteolipid protein (PLP), and MBP) emulsified in adjuvant (e.g. complete Freund's adjuvant (CFA), Pertussis toxin, alum, etc) (Tsunoda \& Fujinami, 1996). Adjuvants potentiate immune reactions (Lavi \& Constantinescu, 2005), ensure persistence of antigens at relevant sites (Lavi \& Constantinescu, 2005), and influence stress response pathways inducing changes in levels of hormones such as ACTH (Selgas et al., 1997), so they can modulate the clinical course of EAE (Libbey \& Fujinami, 2011). On the other hand, passive EAE is induced through adoptive transfer of myelin specific $T$ cells into naïve animals (Tsunoda \& Fujinami, 1996). Both models of EAE induction have been used extensively, with the active model most useful for studying the parameters involved in the initiation of EAE, and the passive model generally used in the study of the effector phase of EAE (Dittel et al., 1999). EAE is polygenic and the susceptibility and the clinical course (acute relapsing, chronic relapsing, relapsing-remitting, chronic progressive) can vary depending on the chosen EAE model and the strain/species of animal being investigated (Lavi \& Constantinescu, 2005; Libbey \& Fujinami, 2011; T. Owens, 2006). 
Therefore, EAE is not a single model, but a number of models that have varying degrees of similarity to MS (Lavi \& Constantinescu, 2005).

Some authors have doubts about the validity of experimental models of MS. However, at present it is accepted that although the preclinical research in MS is merely exploratory, it is also very necessary because it has contributed to elucidating key targets in the pathogenesis of MS. They have helped in the discovery of numerous cytokines and chemokines and the characterization of $\mathrm{T}$ helper cell subsets, thus playing a key role in understanding basic principles of immune function and autoimmunity (Gold et al., 2006). On the other hand, diagnostic, prognostic, and therapeutic aspects of MS have been cleared and resolved by means of experimental models (Pahan, 2010; Steinman \& Zamvil, 2006). In this way, studies on EAE have culminated in three MS therapies (Steinman \& Zamvil, 2006). For example glatiramer acetate, which was approved in 1996 for treatment of relapsing-remitting MS, currently is one of the most popular medications for treatment of relapsing-remitting MS, and more than 100,000 individuals with MS worldwide have received glatiramer acetate treatment (Sela, 2006). Besides, nowadays one of the exciting directions in the development of therapy for MS is consideration of various combinations of medications, and once again EAE models have demonstrated to be a valuable tool. They have shown potential synergies between drugs (statins and glatiramer), which show efficacy when used at doses that are suboptimal for these drugs when used alone (Greenwood et al., 2006; Stüve et al., 2006).

\section{Stress and multiple sclerosis}

The etiology of MS remains unknown, but studies have implicated both genetic and environmental factors (Noseworthy et al., 2000; Sospedra \& Martin, 2005). The notion that psychological stress may be related to MS dates back to the time of Charcot, who suggested that the onset of MS is often preceded by grief or vexation, as well as by other socially undesirable circumstances (Charcot, 1877). Many studies since then have found that MS patients, as compared to healthy people or patients with other neurological disorders, report more stressful experiences prior to initial symptomatology. In the 1980s, two controlled studies were published on this issue. Their results showed that MS patients experienced remarkable life stress more frequently than the control subjects in the year (or six months) prior to MS onset (Grant et al., 1989; Warren et al., 1982). In addition to MS onset, relapses have also been found associated with stressful events (Ackerman et al., 2002; Brown et al., 2005, 2006; Franklin et al., 1988; Golan et al., 2008; Grant et al., 1989; Li et al., 2004; Mohr et al., 2004; Sibley, 1997). Franklin et al. (1988) in a longitudinal prospective study on 55 MS patients, with a clinical evaluation every 4 months for about 2 years, found that patients who reported significant negative or stressful life events were 3.7-times more likely to have an exacerbation than those free of such events. Sibley (1997) also found a significant association $(p<0.02)$ between conjugal or job stress and MS relapses; in the same way that Mohr et al. (2004) in a systematic meta-analysis of 14 prospective studies, published from 1965 to 2003, found that there was a significantly increased risk of exacerbation associated with stressful life events (effect size of $d=0.53$; C.I. $=0.40$ to 0.65 ). In line with previously related studies, this relation has been further cleared by imaging techniques (magnetic resonance imaging) with the marker of acute focal brain inflammation, gadolinium (Goodin et al., 1999). In this way, Mohr et al. (2000) studied a group of 36 MS patients, finding that the occurrence of stressful life events was associated with a significantly increased risk of 
new gadolinium-enhancing $(\mathrm{Gd}+)$ brain lesions. Taken together, these findings and similar observations discovered in animal investigations (Campbell et al., 2001; Chandler et al., 2002; Johnson et al., 2004; Laban et al., 1995a; Meagher et al., 2007; Mi et al., 2004, 2006; Núñez-Iglesias et al., 2010; Pérez-Nievas et al., 2010; Sieve et al., 2004, 2006; Steelman et al., 2009, 2010; Teunis et al., 2002; Welsh et al., 2004; Young et al., 2008, 2010) confirm the necessity of applying preventive and tailored interventions, behavioral and pharmacological, in stressed patients with MS (Golan et al., 2008).

Despite all studies previously commented, some researchers have doubted about the association between the occurrence of stressful life events and the subsequent development of MS disease activity. Pratt (1951) and Gasperini et al. (1995) have not found significant differences between MS patients and control subjects, as far as their experienced stressful events were concerned; and even Nisipeanu and Korczyn (1993) have suggested that psychological stressors could have a "protective effect". Initially it was said that this discrepancy might be the result of a number of research design problems, including infrequent monitoring of patients, small patient samples, subjective reporting bias, type of statistical analysis used, lack of adequate controls, etc (Golan et al., 2008; Goodin, 2008; Martinelli, 2000). However, nowadays it is accepted that the relationship between MS and stressful life events is complex (Brown et al., 2005; Mohr et al., 2000). The type, the timing, and duration of the stressor as well as the animal strain and sex, and the chosen experimental model of MS (Mohr et al., 2004) are factors which determine the result:

a. Type (Table 1): Johnson et al. (2004) observed that if social stress is applied concurrently with Theiler's virus infection, disease severity is reduced compared to infected, nonstressed animals. In contrast, if restraint stress is applied concurrent with infection, the disease is again exacerbated (Campbell et al., 2001; Sieve et al., 2004). Likewise, Bukilica et al. (1991) indicated that whereas 19 daily sessions of inescapable tail-shock $(80,5 \mathrm{~s}, 1$ $\mathrm{mA}$ ) have no effect when administered prior to EAE induction, stressor exposure following EAE induction has a protective effect. Specifically, tail-shock reduces the incidence and duration of EAE, delays disease onset, and decreases the severity of clinical and histological symptoms.

b. Timing and duration (Table 1): Repeated moderate stressors suppress clinical signs when they are given before EAE induction, whereas acute severe stressors enhance the progression of disease after its induction (Heesen et al., 2007). Alternatively, acute stress applied prior to induction of EAE increases the severity of the disease (Teunis et al., 2002), and the contrary (i.e. a protective effect) is observed if the stressor is chronic (Levine \& Saltzman, 1987; Levine et al., 1962; Whitacre et al., 1998).

c. Animal strain (Table 1): Certain inbred mouse strains, including SJL and DBA/2, are very susceptible to persistent CNS infection with TMEV and to the development of TVID, whereas other strains are intermediately susceptible (C3H, AKR, and CBA), and others are still able to clear the virus from the CNS, being resistant to the demyelinating phase of the disease (BALB/c and C57BL/6) (Sieve et al., 2004, 2006; Welsh et al., 1990). For example, Sieve et al. $(2004,2006)$ have observed important differences between CBA and SJL mice. Concretely: first, SJL mice show symptoms of the chronic phase of disease earlier (at 35 days pi) than CBA mice (at 150 days pi); second, SJL mice gradually develop late disease, whereas CBA mice have a sudden onset of severe symptoms; third, the incidence of the chronic phase is higher in SJL than in CBA mice $(100 \%$ of the 


\begin{tabular}{|c|c|c|c|c|}
\hline \multirow[b]{2}{*}{ Study } & \multirow[b]{2}{*}{ Model of MS } & \multirow{2}{*}{$\begin{array}{l}\text { Stressor characteristics } \\
\text { (type, timing, and } \\
\text { duration) }\end{array}$} & \multicolumn{2}{|c|}{ Results } \\
\hline & & & \begin{tabular}{|l|} 
Acute \\
stressor*
\end{tabular} & Chronic stressor** \\
\hline $\begin{array}{l}\text { Pérez-Nievas et } \\
\text { al., } 2010\end{array}$ & $\begin{array}{l}\text { DA rats, EAE } \\
\text { (MOG/CFA) }\end{array}$ & $\begin{array}{l}\text { Restraint stress started } \\
\text { the same day of } \\
\text { induction. Duration: 12d } \\
\text { or 21d }\end{array}$ & & $\begin{array}{l}\text { Exacerbation (12d) } \\
\text { Protective (21d) }\end{array}$ \\
\hline $\begin{array}{l}\text { Núñez-Iglesias } \\
\text { et al., } 2010\end{array}$ & $\begin{array}{l}\text { Lewis rats, EAE } \\
\text { (MBP/CFA) }\end{array}$ & $\begin{array}{l}\text { Noise stress started } 5 d \\
\text { prior to induction. } \\
\text { Duration: } 19 \mathrm{~d} \text { or } 39 \mathrm{~d}\end{array}$ & & $\begin{array}{l}\text { Exacerbation (19d } \\
\text { or 39d) }\end{array}$ \\
\hline $\begin{array}{l}\text { Young et al., } \\
2010\end{array}$ & $\begin{array}{l}\text { SJL/JCrHsd } \\
\text { mice, Theiler } \\
\text { (BeAn strain) }\end{array}$ & $\begin{array}{l}\text { Restraint stress started } \\
\text { the day prior to infection. } \\
\text { Duration: } 28 \mathrm{~d}\end{array}$ & & Exacerbation \\
\hline $\begin{array}{l}\text { Steelman et al., } \\
2010\end{array}$ & $\begin{array}{l}\text { C57BL/ } 6 \text { mice, } \\
\text { Theiler (BeAn } \\
\text { strain) }\end{array}$ & $\begin{array}{l}\text { Restraint stress started } \\
\text { the day prior to infection. } \\
\text { Duration: } 7 \mathrm{~d} \text { or } 4 \mathrm{w}\end{array}$ & & -- \\
\hline $\begin{array}{l}\text { Steelman et al., } \\
2009\end{array}$ & $\begin{array}{l}\text { SJL mice, Theiler } \\
\text { (BeAn strain) }\end{array}$ & $\begin{array}{l}\text { Restraint stress started } \\
\text { the day prior to infection. } \\
\text { Duration: } 8 \mathrm{~d}\end{array}$ & & Exacerbation \\
\hline $\begin{array}{l}\text { Young et al., } \\
2008\end{array}$ & \begin{tabular}{|l|} 
CBA mice, \\
Theiler (BeAn \\
strain) \\
\end{tabular} & $\begin{array}{l}\text { Restraint stress started } \\
\text { the day prior to infection. } \\
\text { Duration: } 4 \mathrm{w} \\
\end{array}$ & & Exacerbation \\
\hline $\begin{array}{l}\text { Meagher et al., } \\
2007\end{array}$ & \begin{tabular}{|l|} 
Balb/cJ mice, \\
Theiler (BeAn \\
strain) \\
\end{tabular} & \begin{tabular}{|l|} 
Social disruption stress \\
started 1w before \\
infection. Duration: $7 \mathrm{~d}$ \\
\end{tabular} & & Exacerbation \\
\hline $\begin{array}{l}\text { Mi et al., 2004, } \\
2006\end{array}$ & \begin{tabular}{|l} 
CBA mice, \\
Theiler (BeAn \\
strain) \\
\end{tabular} & $\begin{array}{l}\text { Restraint stress started } \\
\text { the day prior to infection. } \\
\text { Duration: } 2 \text { or } 7 \mathrm{~d}\end{array}$ & Exacerbation & Exacerbation \\
\hline Sieve et al., 2006 & \begin{tabular}{|l|} 
CBA mice, \\
Theiler (BeAn \\
strain) \\
\end{tabular} & $\begin{array}{l}\text { Restraint stress started } \\
\text { the day prior to infection. } \\
\text { Duration: } 4 \mathrm{w} \\
\end{array}$ & & Exacerbation \\
\hline $\begin{array}{l}\text { Johnson et al., } \\
2004\end{array}$ & $\begin{array}{l}\text { Balb/cJ mice, } \\
\text { Theiler (BeAn } \\
\text { strain) }\end{array}$ & $\begin{array}{l}\text { Social disruption stress } \\
\text { started: } \\
\text { * } 1 \mathrm{w} \text { prior to infection or } \\
\text { * the day of infection } \\
\text { Duration: } 7 \mathrm{~d}\end{array}$ & & $\begin{array}{l}\text { Exacerbation (stress } \\
\text { applied prior to } \\
\text { infection) } \\
\text { Protective (stress } \\
\text { applied concurrent } \\
\text { with infection) }\end{array}$ \\
\hline Sieve et al., 2004 & $\begin{array}{l}\text { SJL mice, Theiler } \\
\text { (BeAn strain) }\end{array}$ & $\begin{array}{l}\text { Restraint stress started } \\
\text { the day prior to infection. } \\
\text { Duration: } 4 \mathrm{w}\end{array}$ & & Exacerbation \\
\hline Welsh et al., 2004 & $\begin{array}{l}\text { CBA mice, } \\
\text { Theiler (BeAn } \\
\text { strain) }\end{array}$ & $\begin{array}{l}\text { Restraint stress started } \\
\text { the day prior to infection. } \\
\text { Duration: } 4 \mathrm{w}\end{array}$ & & Exacerbation \\
\hline $\begin{array}{l}\text { Anane et al., } \\
2003\end{array}$ & $\begin{array}{l}\text { Lewis rats, EAE } \\
\text { (MBP/CFA) }\end{array}$ & $\begin{array}{l}\text { Physical stress } \\
\text { (microwaves) started the } \\
\text { day of induction. } \\
\text { Duration: } 21 \mathrm{~d} \\
\end{array}$ & & --- \\
\hline $\begin{array}{l}\text { Chandler et al., } \\
2002\end{array}$ & $\begin{array}{l}\text { SJL/J mice, EAE } \\
\text { (PLP/CFA) }\end{array}$ & \begin{tabular}{|l|} 
Restraint stress was \\
performed on days 2 and \\
3 post-induction. \\
Duration: $2 \mathrm{~d}$ \\
\end{tabular} & Exacerbation & \\
\hline
\end{tabular}




\begin{tabular}{|c|c|c|c|c|}
\hline \multirow[b]{2}{*}{ Study } & \multirow[b]{2}{*}{ Model of MS } & \multirow{2}{*}{$\begin{array}{l}\text { Stressor characteristics } \\
\text { (type, timing, and } \\
\text { duration) }\end{array}$} & \multicolumn{2}{|c|}{ Results } \\
\hline & & & $\begin{array}{l}\text { Acute } \\
\text { stressor* }\end{array}$ & Chronic stressor ${ }^{* *}$ \\
\hline $\begin{array}{l}\text { Teunis et al., } \\
2002\end{array}$ & $\begin{array}{l}\text { Wistar rats, EAE } \\
\text { (MBP/CFA) }\end{array}$ & $\begin{array}{l}\text { Neonatal maternal } \\
\text { deprivation was } \\
\text { performed aprox. } 7 \mathrm{w} \\
\text { before induction. } \\
\text { Duration: } 24 \mathrm{~h} \\
\end{array}$ & Exacerbation & \\
\hline $\begin{array}{l}\text { Campbell et al., } \\
2001\end{array}$ & \begin{tabular}{|l|} 
CBA mice, \\
Theiler (BeAn \\
strain)
\end{tabular} & $\begin{array}{l}\text { Restraint stress started } \\
\text { the day prior to infection. } \\
\text { Duration: } 4 \mathrm{w}\end{array}$ & & Exacerbation \\
\hline $\begin{array}{l}\text { Dowdell et al., } \\
1999\end{array}$ & $\begin{array}{l}\text { B10.PL mice, EAE } \\
\text { (MBP/CFA) }\end{array}$ & $\begin{array}{l}\text { Restraint stress started } \\
\text { the day prior to } \\
\text { induction. Duration: 21d }\end{array}$ & & Protective \\
\hline $\begin{array}{l}\text { Whitacre et al., } \\
1998\end{array}$ & $\begin{array}{l}\text { Lewis rats, EAE } \\
(\mathrm{MBP} / \mathrm{CFA})\end{array}$ & $\begin{array}{l}\text { Restraint stress started } 5 \\
\text { days prior to induction. } \\
\text { Duration: } 23 \mathrm{~d}\end{array}$ & & $\begin{array}{l}\text { Protective }(9 \mathrm{~h} \text { of } \\
\text { stress } / \mathrm{d}) \\
\text { Exacerbation }(1 \text { or } \\
12 \mathrm{~h} \text { of stress } / \mathrm{d})\end{array}$ \\
\hline $\begin{array}{l}\text { Correa et al., } \\
1998\end{array}$ & $\begin{array}{l}\text { Wistar rats, EAE } \\
\text { (MBP/CFA) }\end{array}$ & $\begin{array}{l}\text { Varied stress (swimming, } \\
\text { predator odor, water } \\
\text { deprivation, crowding, } \\
\text { restraint, high-intensity } \\
\text { sound, and cage } \\
\text { inclination) was } \\
\text { performed for the } 14 \mathrm{~d} \\
\text { before or after induction. } \\
\text { Duration: } 2 \mathrm{w} \\
\end{array}$ & & $\begin{array}{l}\text { Protective (stress } \\
\text { before induction) } \\
\text { Exacerbation (stress } \\
\text { after induction) }\end{array}$ \\
\hline $\begin{array}{l}\text { Owhashi et al., } \\
1997\end{array}$ & $\begin{array}{l}\text { Lewis rats, EAE } \\
\text { (MBP/CFA) }\end{array}$ & $\begin{array}{l}\text { Water bath }\left(44^{\circ} \mathrm{C}\right) \text { was } \\
\text { performed for the } 10 \text { or } \\
\text { 13d before or after the } \\
\text { induction. Duration: } 10 \text { or } \\
13 \mathrm{~d}\end{array}$ & $\begin{array}{l}- \text { (stress } \\
\text { before } \\
\text { induction) } \\
\text { Protective } \\
\text { (stress after } \\
\text { induction) } \\
\end{array}$ & \\
\hline $\begin{array}{l}\text { Le Page et al., } \\
1996\end{array}$ & $\begin{array}{l}\text { Lewis rats, } \\
\text { adoptive EAE }\end{array}$ & $\begin{array}{l}\text { Physical exercise was } \\
\text { performed the } 2 \mathrm{~d} \text { before } \\
\text { or after the adoptive } \\
\text { transfer of EAE. } \\
\text { Duration: } 2 \mathrm{~d}\end{array}$ & $\begin{array}{l}-- \text { (stress } \\
\text { before } \\
\text { induction) } \\
\text { Scantily } \\
\text { protective } \\
\text { (stress after } \\
\text { induction) } \\
\end{array}$ & \\
\hline $\begin{array}{l}\text { Laban et al., } \\
\text { 1995a }\end{array}$ & $\begin{array}{l}\text { DA rats, EAE } \\
\text { (SCH/CFA) }\end{array}$ & $\begin{array}{l}\text { Neonatal handling or } \\
\text { gentling was performed } \\
\text { 8w before induction. } \\
\text { Duration: } 4 w \\
\end{array}$ & Exacerbation & \\
\hline $\begin{array}{l}\text { Laban et al., } \\
\text { 1995b }\end{array}$ & $\begin{array}{l}\text { DA rats, EAE } \\
(\mathrm{SCH} / \mathrm{CFA})\end{array}$ & \begin{tabular}{|l|} 
Maternal deprivation was \\
performed 8 w before \\
induction. Duration: $28 \mathrm{~d}$ \\
Early weaning was \\
performed for $5-6 \mathrm{w}$ \\
before induction. \\
Duration: $1-2 \mathrm{w}$ \\
\end{tabular} & & $\begin{array}{l}\text { Protective } \\
\text { (maternal } \\
\text { deprivation } \\
\text { Exacerbation (early } \\
\text { weaning) }\end{array}$ \\
\hline
\end{tabular}




\begin{tabular}{|c|c|c|c|c|}
\hline \multirow[b]{2}{*}{ Study } & \multirow[b]{2}{*}{ Model of MS } & \multirow{2}{*}{$\begin{array}{l}\text { Stressor characteristics } \\
\text { (type, timing, and } \\
\text { duration) }\end{array}$} & \multicolumn{2}{|c|}{ Results } \\
\hline & & & $\begin{array}{l}\text { Acute } \\
\text { stressor* }\end{array}$ & Chronic stressor ${ }^{* *}$ \\
\hline $\begin{array}{l}\text { Le Page et al., } \\
1994\end{array}$ & $\begin{array}{l}\text { Lewis rats, EAE } \\
(\mathrm{SCH} / \mathrm{CFA})\end{array}$ & $\begin{array}{l}\text { Physical exercise was } \\
\text { performed for the } 10 \text { days } \\
\text { after induction. Duration: } \\
\text { 10d }\end{array}$ & & Protective \\
\hline $\begin{array}{l}\text { Dimitrijević et } \\
\text { al., } 1994\end{array}$ & $\begin{array}{l}\text { Lewis and DA } \\
\text { rats, EAE } \\
(\mathrm{SCH} / \mathrm{CFA})\end{array}$ & $\begin{array}{l}\text { Neonatal sound stress } \\
\text { was performed } 2 \text { or } 3 \mathrm{w} \\
\text { before induction. } \\
\text { Duration: } 1 \mathrm{~h}\end{array}$ & $\begin{array}{l}\text { Exacerbation } \\
\text { (Lewis) } \\
\text { Protective } \\
\text { (DA) } \\
\end{array}$ & \\
\hline $\begin{array}{l}\text { Kuroda et al., } \\
1994\end{array}$ & $\begin{array}{l}\text { Lewis rats, EAE } \\
(\mathrm{SCH} / \mathrm{CFA})\end{array}$ & $\begin{array}{l}\text { Restraint stress was } \\
\text { performed } 1 \text { or } 8 \mathrm{~d} \text { after } \\
\text { induction. Duration: } 3 \mathrm{~d}\end{array}$ & $\begin{array}{l}--(1 \mathrm{~d}) \\
\text { Protective }(8 \mathrm{~d})\end{array}$ & \\
\hline $\begin{array}{l}\text { Griffin et al., } \\
1993\end{array}$ & $\begin{array}{l}\text { Lewis rats, EAE } \\
\text { (MBP/CFA) }\end{array}$ & $\begin{array}{l}\text { Restraint stress started } 5 \mathrm{~d} \\
\text { before induction. } \\
\text { Duration: } 23 \mathrm{~d}\end{array}$ & & Protective \\
\hline $\begin{array}{l}\text { Bukilica et al., } \\
1991\end{array}$ & $\begin{array}{l}\text { DA rats, EAE } \\
(\mathrm{SCH} / \mathrm{CFA})\end{array}$ & $\begin{array}{l}\text { Electric stress or sound } \\
\text { stress was performed the } \\
\text { 19d before or after } \\
\text { induction. Duration: 19d }\end{array}$ & & $\begin{array}{l}\text { Protective (electric } \\
\text { stress after } \\
\text { induction and } \\
\text { sound stress) } \\
\text {--- (electric stress } \\
\text { before induction) } \\
\end{array}$ \\
\hline
\end{tabular}

Table 1. Animal studies (published from 1991 to 2010) on the effects of stress on disease manifestation. Studies are classified according to the type of stressor used: acute or chronic. ${ }^{*}$ Acute stressor, stressor lasting less than $1 \mathrm{~h}$ and for less than 5 days; ** chronic stressor, stressor lasting longer than $1 \mathrm{~h}$ and more than 5 days (although in most instances they were not presented all through the day). Abbreviations. CFA, complete Freund's adjuvant; $d$, day; DA, Dark August; EAE, experimental autoimmune encephalomyelitis; h, hour; MBP, myelin basic protein; MOG, myelin oligodendrocyte glycoprotein; PLP, proteolipid protein; $\mathrm{SCH}$, spinal cord homogenate; $w$, week.

SJL mice develop severe symptoms of the chronic phase of the disease, versus to $70 \%$ (at most) of the CBA mice) (Friedmann \& Lorch, 1985; Oleszak et al., 2004; Simas \& Fazakerley, 1996). Susceptibility to TMEV persistence and TVID has been linked to genetic differences between strains of mice (Bureau et al., 1993; Monteyne et al., 1997; Oleszak et al., 2004; Rodriguez et al., 1990), which could explain the variability in their responsivity to stress and their different immunological background. In relation to EAE, it has also been shown that the susceptibility varies depending on the strain. So, whereas $\mathrm{ABH}$ and SJL mice develop relapsing EAE to disease induced by whole myelin, C57BL/ 6 mice are resistant (Lavi \& Constantinescu, 2005).

d. Sex: A very discussed topic has been the sex impact in the disease process (Hill et al., 1998; Kappel et al., 1990; Lipton, 1975; Sieve et al., 2004, 2006). In some studies, female SJL mice are known to have greater susceptibility to disease as compared to males, a pattern that is similar to that found in human MS patients (Hill et al., 1998; Kappel et al., 1990; Sieve et al., 2004); on the contrary, other studies indicate that male mice develop more severe symptomatology of disease than females (Alley et al., 2003). It has been suggested that these apparently contradictory results may be due to different study 
designs and criteria used such as housing conditions or strain of Theiler's virus (Sieve et al., 2004). However, the sexual dimorphism of the immune system, the stress systems or the bidirectional communication between the reproductive system and the stress systems are reasons which may also explain, at least in part, this discrepancy (Gaillard \& Spinedi, 1998; Whitacre et al., 1999). On the other hand, it is important to emphasize that the pattern of sex differences found can be complex. Sometimes, there are no sex differences in the early viral infection, existing on the contrary, greater behavioral signs in males than in females in later disease (Sieve et al., 2004).

e. Experimental model of MS (Table 1): Several authors have observed that stress exacerbates the early viral infection (Campbell et al., 2001; Sieve et al., 2004) and the later demyelinating disease (Sieve et al., 2004) in Theiler's virus infection. However, this does not coincide with studies using EAE, which show no effect of stress prior to disease induction, and a suppression during disease induction (Bukilica et al., 1991; Dowdell et al., 1999; Griffin et al., 1993; Levine \& Saltzman, 1987; Levine et al., 1962). The differences in how stress affects EAE and Theiler's virus infection may lie in their immunological mechanisms of demyelination and neuronal destruction. However, the observed discrepancy between these two experimental models of MS can also be attributed to the fact that the stressor is applied during different phases in the immunological response of the disease process (Sieve et al., 2004).

\section{Effects and mechanisms of action of benzodiazepines on models of MS}

Benzodiazepines (alone or in association with other therapies) have long been used to relieve or resolve symptoms and signs associated with MS (Arroyo et al., 2011; Bush et al., 1996; D'Aleo et al., 2011; Hung \& Huang, 2007; Meythaler et al., 1991; Rode et al., 2003; Solaro et al., 2010; Stork \& Hoffman, 1994; Velez et al., 2003; Yerdelen et al., 2008). For example, Hung and Huang (2007) have observed that a combination of lorazepam and diazepam may be considered to release catatonic features in patients with MS, although the prescription of benzodiazepines associated with electroconvulsive therapy is another therapeutic option commonly used (Bush et al., 1996; Hung \& Huang, 2007). Likewise, painful spasms, tremors or seizures (with or without associated anxiety symptoms) are treated with benzodiazepines such as clonazepam (Rode et al., 2003; Yerdelen et al., 2008), diazepam (D'Aleo et al., 2011; Meythaler et al., 1991; Rode et al., 2003) or tetrazepam (Rode et al., 2003); and even, Velez et al. (2003) have observed that patients with dramatic opisthotonic posturing and vermiform tongue fasciculations respond well to intravenous doses of lorazepam.

Benzodiazepines are used clinically as tranquilizers, muscle relaxants, anticonvulsants, anxiolytics, and sedative-hypnotics. These effects are mediated primarily via the central benzodiazepine receptors (CBR) located in the CNS (Heiss \& Herholz, 2006); however, in addition to binding of $\mathrm{GABA}_{\mathrm{A}}$ receptors in the $\mathrm{CNS}$, benzodiazepines bind to another site in peripheral tissues. This second type of recognition sites was mistakenly termed "peripheral benzodiazepine receptor" (PBR) for many years (Table 2). However, at present scientists prefer using the nomenclature: translocator protein (18 kDa) (TSPO) (Papadopoulos et al., 2006a). The TSPO is different from the CBR in terms of function, structure, expression, and pharmacological action (Gavish et al., 1999; Woods \& Williams, 1996), so their study must be performed separately. 


\subsection{Effects mediated by the CBR}

To date, only one study has been conducted to examine the influence of central benzodiazepine agonists on the development of animal models of MS (Núñez-Iglesias et al., 2010). Núñez-Iglesias et al. (2010) have observed that alprazolam decreases the clinical (paralysis, paraplegia, piloerection, etc) and histological (perivascular inflammatory infiltrate) manifestations of acute EAE in Lewis rats exposed to a chronic auditory stressor.

The molecular mechanisms mediating the clinical effects of central benzodiazepines in animal models of MS are unknown. However, it is thought that stress response mediators might play an important role in them.

\begin{tabular}{|l|l|l|}
\hline Structure & CBR & TSPO \\
\hline $\begin{array}{l}\text { Part of a macromolecular } \\
\text { complex that also contains a } \gamma \text { - } \\
\text { aminobutyric acid (GABA } \\
\text { receptor site and a chloride ion } \\
\text { channel (Heiss \& Herholz, 2006). }\end{array}$ & $\begin{array}{l}\text { Part of a hetero-oligomeric complex comprised } \\
\text { of the voltage-dependent anion channel and an } \\
\text { adenine nucleotide carrier (McEnery et al., } \\
\text { 1992; Papadopoulos et al., 2006a). }\end{array}$ \\
\hline localization & $\begin{array}{l}\text { Plasma membrane of neurons } \\
\text { (Heiss \& Herholz, 2006). }\end{array}$ & $\begin{array}{l}\text { Mitochondrial outer membrane (Gavish et al., } \\
\text { 1999; Heiss \& Herholz, 2006). }\end{array}$ \\
\hline Localization & $\begin{array}{l}\text { Nonmitochondrial localization: plasma } \\
\text { central: medial occipital cortex, } \\
\text { pons (Heiss \& Herholz, 2006). }\end{array}$ & $\begin{array}{l}\text { 1988), nucleus, and perinuclear area (Gavish et } \\
\text { al., 1999; Kuhlmann \& Guilarte, 2000). }\end{array}$ \\
$\begin{array}{l}\text { Peripheral: kidney (Gavish et al., 1999), lung } \\
\text { (Gavish et al., 1999), skeletal muscle (Gavish et } \\
\text { al., 1999), liver (Gavish et al., 1999), heart } \\
\text { (Gavish et al., 1999), uterus (Gavish et al., } \\
\text { 1999), testis (Gavish et al., 1999), ovaries } \\
\text { (Cosenza-Nashat et al., 2009; Gavish et al., } \\
\text { 1999), haematogenous cells (Cosenza-Nashat et } \\
\text { al., 2009; Olson et al., 1988; Ruff et al., 1985), } \\
\text { and the steroid hormone-producing cells of the } \\
\text { adrenal cortex (Gavish et al., 1999). } \\
\text { Central (low concentrations): principally non- } \\
\text { neuronal cells: ependymal lining of the } \\
\text { ventricles, choroid plexus (Mattner et al., } \\
\text { 2005), and glial cells (astrocytes and microglia) } \\
\text { (Cosenza-Nashat et al., 2009; Mattner et al., } \\
\text { 2005). Some studies also suggest that neurons } \\
\text { may express TSPO (Jayakumar et al., 2002). }\end{array}$ \\
\hline
\end{tabular}

Table 2. Benzodiazepine binding sites. Main differences between CBR (central benzodiazepine receptor) and TSPO (translocator protein $(18 \mathrm{kDa})$, also known as: peripheral-type benzodiazepine binding site, peripheral benzodiazepine receptor or mitochondrial benzodiazepine receptor). 


\subsubsection{Psychoneuroimmunoendocrinology and MS}

Stress affects host defenses comprising neuronal, endocrine, and immune reactions. This complex network of bi-directional signals plays a vital role in determining the outcome of the stress response, since when the balance among these systems is altered, the risk of disease increases (Masood et al., 2003).

Figure 1 shows how stress impairs both natural and specific immune responses, which could influence morbidity associated with MS. Changes in the absolute number of lymphocytes, T-lymphocytes, T-helper, and T-suppressor cells have been reported (FreireGarabal et al., 1991, 1997). Stress also interferes with several immune responses such as splenic cytotoxic activities, mediated by NK cells and cytotoxic T lymphocytes (Núñez et al., 2006), the activity of phagocytosis (Freire-Garabal et al., 1993a, 1993b), the delayed type hypersensitivity (DTH) response (Freire-Garabal et al., 1997; Núñez et al., 1998; VarelaPatiño et al., 1994), the blastogenic response of spleen lymphoid cells (Freire-Garabal et al., 1991, 1997), and T-dependent antibody responses (Fukui et al., 1997).

Research into the mechanisms by which the stressors are translated into impaired immune function and vulnerability to disease has focused primarily on two pathways: the hypothalamic-pituitary-adrenal (HPA) axis and the sympathetic branch of the autonomic nervous system (ANS) (Figure 1). Whereas increased sympathetic adrenal activity appears to play a major role in immune changes observed after acute stress, HPA axis-activity together with sympathetic mechanisms are mainly responsible for the inhibition of cellular and humoral immune responses following chronic stress exposure (Glaser \& Kiecolt-Glaser, 2005). The importance of these systems is so high that when neuroendocrine hyper- or hypoactive responses of the HPA axis or the sympathetic nervous system (SNS) to stress occur, they function as risk factors of specific diseases, such as neurodegenerative diseases. Concretely, Gold et al. (2005) highlight the relevance of the functional status of the HPA axis in the control of EAE. During the experimentally induced disease in animals, the endogenous levels of glucocorticoids are elevated and the recovery from the disease is clearly dependent on this endocrine change (MacPhee et al., 1989). This endocrine response is immunologically mediated so it is mainly the result of the stimulation of the HPA axis by cytokines (such as IL-1) produced during the immune response that induces the autoimmune disease (Del Rey et al., 1998). In EAE models, the negative feedback system mediated via the glucocorticoid receptors seems to be disturbed (Gold et al., 2005), with the stressors favoring the perpetuation of this disregulation, as is shown by increased corticosterone levels in stressed rats relative to unstressed animals (Núñez-Iglesias et al., 2010). The importance of an increased HPA axis activity is supported by the observation that this phenomenon is related to the clinical disease course (Then Bergh et al., 1999).

The most basic literature regarding the HPA axis in pharmacology studies has been obtained in rats. More recently the mouse has been used due to the availability of genetically manipulated mice. The mouse is a model species of choice for genetic engineering because: a) its genes have an equivalent in humans; b) its genome is easy to modify by homologous recombination; c) it allows the creation of relevant animal models of human disease; d) numerous biological and biochemical functions of the mouse are similar to those of humans; e) it is easy to breed, less expensive to feed than rats and lives in smaller cages. These genetic models have allowed the determination of genes involved in anatomic and 


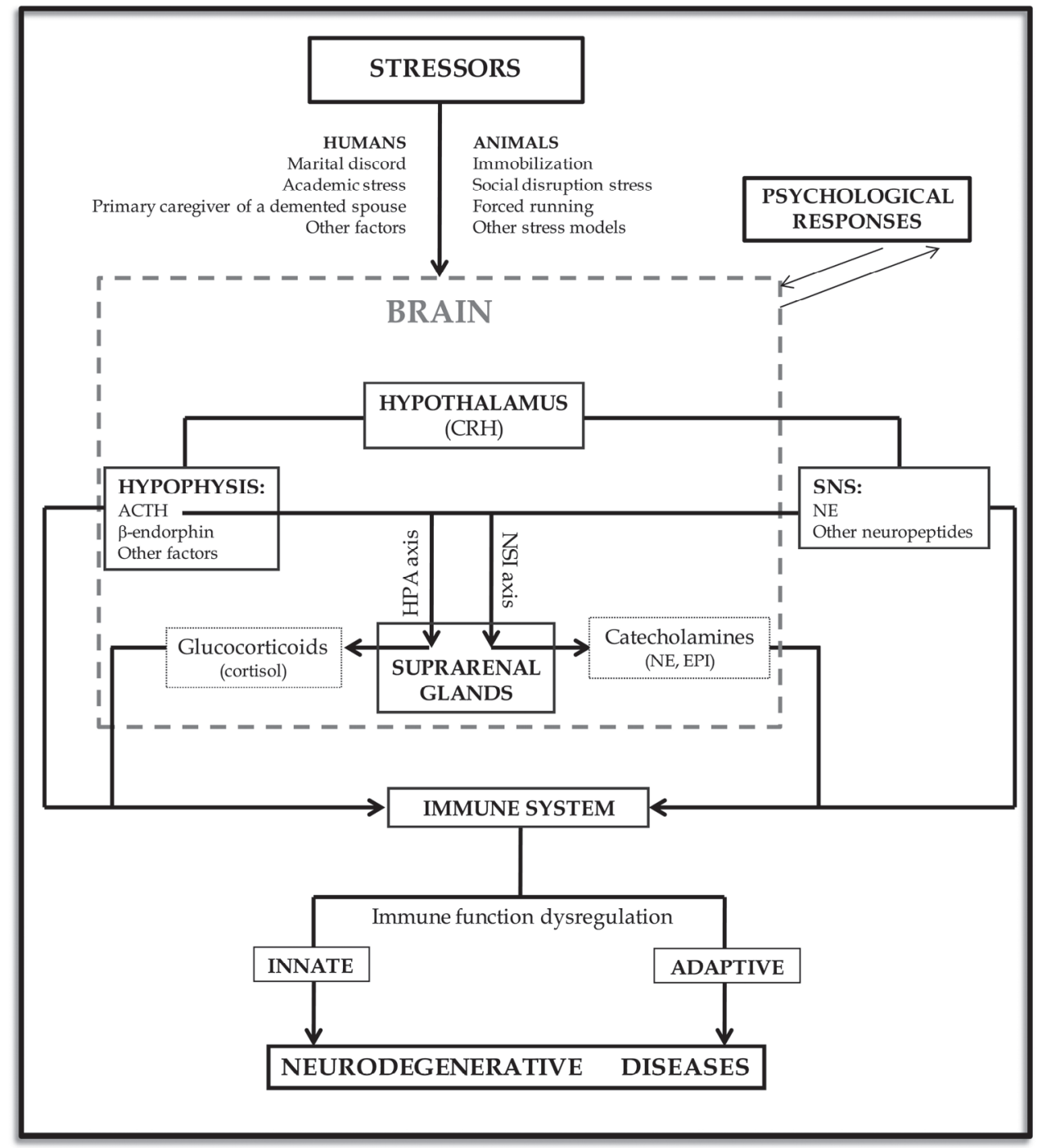

Fig. 1. Biological pathways mediating stress-induced modulation of immune function. The hypothalamic-pituitary-adrenal (HPA) axis and the neocortical-sympathetic-immune (NSI) axis are the main neural efferent pathways through which stress can affect the activity of the immune system. Stress-induced impairments in immunity can influence morbidity associated with neurodegenerative diseases. Abbreviations: ACTH, adrenocorticotropic hormone; $\mathrm{CRH}$, corticotropin releasing hormone; EPI, epinephrine; NE, norepinephrine; SNS, sympathetic nervous system. Own production. Source: Friedman \& Lawrence (2002) and Godbout \& Glaser (2006). 
functional alterations of brain circuits critical for stress regulation. Furthermore, they have contributed to understanding genetic vulnerability to anxiety and its pharmacological treatment (Gardier et al., 2009).

\subsubsection{Benzodiazepines for control of stress associated with MS}

Several mechanisms could explain the effects mediated by central benzodiazepines on attenuated manifestations of MS:

a. Inhibitory influence on the activity of the HPA axis.

GABA and benzodiazepines reduce levels of HPA axis hormones, including CRF (corticotropin releasing hormone) and ACTH (adrenocorticotropic hormone) and corticosterone (Arvat et al., 2002; Bizzi et al., 1984; M.J. Owens et al., 1989) acting on CBR. Central pharmacological effects related to CBR acting by facilitating inhibitory GABA neurotransmission in the CNS, may regulate the release of neuroendocrine hormones involved in the immune response to stress.

\section{b. Platelet activating factor (PAF) antagonist properties.}

Activation and control of the coagulation cascade, modulated by antigen-specific mediators of cellular immunity, appear to be of prime importance in the animal models of MS (Inoue et al., 1996). Susceptibility and resistance to EAE in rodents correlate with the induction of procoagulant and anticoagulant activities. Geczy et al. (1984) observed that anticoagulants produced by cells from nonsusceptible EAE rodents suppressed the common coagulation pathway by inhibiting trombin and factor Xa activities.

Central benzodiazepines such as alprazolam have PAF antagonist properties. It was found that in washed human platelets the alprazolam potently inhibits PAF-induced changes in shape, aggregation, and secretion, with the effects being specific for PAF activation (Kornecki et al., 1984). Likewise, Ng and Wong (1988) also showed that alprazolam can inhibit the $\left[{ }^{3} \mathrm{H}\right] \mathrm{PAF}$ binding to the human peripheral blood mononuclear leukocytes. In this context, it is interesting to point out that PAF plays a role in the activation of the HPA axis and glucocorticoid secretion and can serve as a mediator in the interactions of the immune system with the CNS. Concretely, PAF is an activator of the HPA axis in the rat. Its activation, which causes significant stimulation of hypothalamic $\mathrm{CRH}$, pituitary $\mathrm{ACTH}$, and adrenal corticosterone secretion, is inhibited by alprazolam. In addition, the PAF stimulates ACTH secretion by dispersed rat pituicytes, which is also inhibited by the alprazolam (Bernardini et al., 1989). The specific antagonism of PAF action by psychotropic drugs suggests that PAF or PAF-like phospholipids may play a role in neuronal function (Kornecki et al., 1987).

c. Inhibitory activity on proinflammatory cytokines.

Besides the mechanisms previously described, downstream effects of the alprazolam on immunological and inflammatory parameters important for EAE must be underscored. Secondarily recruited inflammatory cells account for the vast majority of infiltrating cells in MS lesions and they play a pivotal role in CNS tissue damage (Ransohoff, 1999). The detailed mechanisms by which inflammatory cells enter the CNS compartment are not completely understood. However, evidence suggests that cytokines are essential for 
this process (Karpus \& Ransohoff, 1998). Enhanced expression of proinflammatory cytokines in the CNS, such as the monocyte chemoattractant protein 1 (MCP-1), has been demonstrated both in animal models of MS (Juedes et al., 2000) and in human case series (D'Aversa et al., 2002), and Karpus et al. (1997) have showed that the severity of manifestations is reduced by anti-MCP-1 antibodies. Additionally, mice that lack C-C chemokine receptor 2 (CCR2), the major receptor on monocytes for MCP-1, fail to develop the disease after active immunization (Fife et al., 2000) and are resistant to induction of it by the adoptive transfer of primed T cells from syngenic wild-type mice (Izikson et al., 2000). The effect of alprazolam on the expression levels of cytokines has been studied (Chang et al., 1992; Oda et al., 2002). Oda et al. (2002) have noted a potent inhibitory activity of this benzodiazepine on IL- $1 \alpha$-elicited MCP-1 production in T98G cells. Likewise, alprazolam inhibits the production of cytokines IL-1 $\beta$ and MCP-1 in LPS-stimulated mouse macrophage cells (Oda et al., 2002) and reduces the production of IL-2 by murine splenic T-cells (Chang et al., 1992). These findings suggest that alprazolam might prevent the infiltration of specific regions by an excess of proinflammatory cytokines. Since the excess production of proinflammatory cytokines exacerbates MS or EAE (Karpus \& Ransohoff, 1998), the above-described action of alprazolam might explain the improvement of manifestations associated with EAE in non-human species or patients treated with this drug.

\subsection{Effects mediated by the TSPO}

Microglia play a significant role in the pathogenesis of MS (Venneti et al., 2006). They serve housekeeping functions and maintain homeostasis of local environments (Davalos et al., 2005; Nimmerjahn et al., 2005). In response to CNS insults, microglia change from a resting to an activated state to function as phagocytic macrophages (Chan et al., 2003; Fetler \& Amigorena, 2005). This transition of microglia into an activated state includes a change in their morphology, migration towards the site of neuronal damage, proliferation until they quadruplicate in number (Davalos et al., 2005; Fetler \& Amigorena, 2005), overexpression of cell markers (Agnello et al., 2000; Banati et al., 1997, 2000; Debruyne et al., 2003; Gavish et al., 1999; Kuhlmann \& Guilarte, 2000; Versijpt et al., 2005; Vowinckel et al., 1997), and release of a widespread variety of substances or molecules (Chao et al., 1992, 1995a, 1995b; Colton et al., 1993; D'Aversa et al., 2002; Giulian et al., 1986, 1990; Heyes et al., 1996; McManus et al., 1998; Murphy et al., 1995; Righi et al., 1989). These findings demonstrate that microglia (together with perivascular macrophages -Guillemin \& Brew, 2004-) represent a first line of the immune defense system of the brain (Davalos et al., 2005; Fetler \& Amigorena, 2005; Nimmerjahn et al., 2005), and justify their description as a "sensor for pathological events in the CNS" (Kreutzberg, 1996). Parallel to this protective function, microglia can also contribute to aggravating the underlying neuronal damage via the synthesis and release of neurotoxins (Chao et al., 1992, 1995a; Colton et al., 1993; Giulian et al., 1990; Heyes et al., 1996), cytokines (Chao et al., 1995b; Giulian et al., 1986; Righi et al., 1989), and chemokines (D'Aversa et al., 2002; McManus et al., 1998; Murphy et al., 1995). Taking into account these results, it is concluded that microglia can exist in different states of activation depending on the microenvironment, with some states favoring the secretion of substances damaging neurons and other states favoring a protective phagocytic role (Morgan et al., 2005).

Microglia must maintain the balance between neurotoxicity and neuroprotection in injury, but the complex network of factors which governs their responses is only beginning to be 
deciphered (Biber et al., 2007; Glezer et al., 2007). Certainly, it would be interesting if some components of the network of microglial control could be manipulated for prognostic or therapeutic purposes of MS (Rock \& Peterson, 2006). In this regard, TSPO plays a very important role. TSPOs are involved in the regulatory processes and metabolic functions of the tissue in which they are present. Outside the CNS: i) it is thought to aid in the transport of cholesterol from the outer to the inner mitochondrial membranes and thus be vital in steroid synthesis (Papadopoulos et al., 1997); ii) as a constituent of the mitochondrial permeability transition pore, TSPO is believed to regulate cell death (McEnery et al., 1992) and mitochondrial respiration (Hirsch et al., 1989); iii) evidence for an immunomodulatory role for this receptor includes the ability to: modulate chemotaxis and phagocytosis in peripheral monocytes and neutrophils (Marino et al., 2001; Ruff et al., 1985), induce cytokine expression and superoxide generation (Zavala et al., 1990), regulate macrophage functions (Pawlikowski, 1993), and stimulate formation of antibody-producing cells (Zavala \& Lenfant, 1987), among others (Gavish et al., 1999); iv) TSPO is also thought to play a role in cell proliferation and differentiation (Camins et al., 1995), in protein and ion transport (Casellas et al., 2002; Gavish et al., 1999), and in bile acid synthesis (Lacapère \& Papadopoulos, 2003; Woods \& Williams, 1996). On the other hand, the functions of this receptor within the CNS are less known. It is suggested that it is involved in neurosteroid synthesis (Papadopoulos et al., 2006b), regulating mitochondrial function (Casellas et al., 2002), and modulating neuroinflammation in microglial cells (Wilms et al., 2003). The fact that TSPO knockout mice die at an early embryonic stage (Papadopoulos et al., 1997) strongly suggests that TSPO is involved in basic cell functions and is essential for embryonic development.

The main findings derived from the study of TSPO in MS patients or animal models of MS are detailed next:

\section{a. TSPO as in vivo marker of neuronal damage in MS.}

Reactive gliosis based on morphological examination is a microscopic finding in brain tissue sections and can only be obtained from invasive biopsy or postmortem autopsy. Therefore, the development and validation of an in vivo biomarker of glial damage is a major advance in the neurology field. In this way, the visualisation of the TSPO has received great importance in MS patients.

TSPO is expressed in the undamaged CNS at only a low level (Agnello et al., 2000; Banati et al., 2000; Gavish et al., 1999); however, its expression is dramatically increased (mainly on microglia and in minor importance on astrocytes) in inflammatory diseases such as MS (Banati et al., 2000; Debruyne et al., 2003; Versijpt et al., 2005; Vowinckel et al., 1997) and animal models of MS (Agnello et al., 2000; Banati et al., 2000; Gavish et al., 1999; Vowinckel et al., 1997). This up-regulation, which reflects an activation of resident microglia, can be visualized and measured using in vitro receptor autoradiography and binding assays as well as in vivo imaging techniques, such as PET (Maeda et al., 2004). So, in recent years a number of PET ligands with affinity to the TSPO have been developed and tested (e.g. Ro5-4864, PK11195, DAA1106, and vinpocetine) (Junck et al., 1989; Maeda et al., 2004). This has propitiated that nowadays TSPO cellular expression can be considered a reliable biomarker for neuroinflammation and gliosis with neuronal damage (Banati et al., 2000; Debruyne et al., 2003; Mattner et al., 2005; Versijpt et al., 2005; Vowinckel et al., 1997). 


\section{b. Neuroprotective function: anti-inflammatory and anti-apoptotic properties.}

Recent evidence suggests that TSPO may play an important neuroprotective role in MS patients, both for its anti-inflammatory and its anti-apoptotic properties.

\section{b.1 Anti-inflammatory properties.}

Some investigations point to the possibility that the TSPO may participate actively in neuroinflammation and may thus itself be a target for therapeutic intervention. In this way, it has been demonstrated that TSPO ligands (Choi et al., 2002; Ryu et al., 2005) and some benzodiazepines (Wilms et al., 2003) possess anti-inflammatory properties. The PK11195 ligand inhibits increases in cyclooxygenase-2 levels in cultured human microglia (Choi et al., 2002), decreases expression of pro-inflammatory cytokines (IL-1 $\beta$, IL-6, TNF-a) (Choi et al., 2002; Ryu et al., 2005) and reduces neuronal death in the quinolinic acid-injected rats (Ryu et al., 2005). Likewise, Wilms et al. (2003) have observed that midazolam, clonazepam, and diazepam interfere with the synthesis and release of proinflammatory (TNF- $\alpha$ ) and neurotoxic (nitric oxide -NO-) molecules generated by activated microglia in vitro. The anti-inflammatory action associated to TSPO is not exclusive for microglial cells, it has also been shown on human blood cells (Bessler et al., 1992; Lenfant et al., 1986; Zavala et al., 1990). It is known that PK11195 and Ro5-4864 inhibit IL-3-like activity secretion in human peripheral blood mononuclear cells, and that IL-2, IL-1, TNF- $\alpha$, and IL-6 production is inhibited by Ro54864 (Bessler et al., 1992; Lenfant et al., 1986). Likewise, treatment of mice with Ro5-4864 markedly reduces the capacity of macrophages to produce key mediators of inflammation such as reactive oxygen intermediates, IL-1, TNF, and IL-6 (Zavala et al., 1990). In particular, TNF is considered an important pharmacological target for the therapy of MS and drugs able to inhibit TNF-synthesis, such as the phosphodiesterase inhibitors, have been reported to ameliorate EAE (Sommer et al., 1995). Taken together, these findings are very promising, specially if we bear in mind that diazepam has been undoubtedly demonstrated to be neuroprotective in experimental models of other diseases (Schwartz-Bloom et al., 2000).

The true meaning of increased TSPO expression in microglia is unknown, however Wilms et al. (2003) have postulated that the presence of a high density of TSPO in human MS might be an adaptive response to neuronal damage with subsequent decreased release of neurotoxic microglial mediators. This hypothesis is supported by findings of Lacor et al. (1999) and Costa et al. (1994). They demonstrated that TSPO density is highly increased after peripheral nerve injury, with TSPO returning to normal levels when regeneration is complete or with TSPO remaining elevated in the absence of regeneration. A possible source of endogenous ligands of TSPO are astrocytes, which release substantial amounts of endozepines (Patte et al., 1999). These findings suggest that TSPO may be a trophic factor in recovery from brain injury.

A lot has been speculated about the mechanisms by which TSPO specific ligands confer protection. However, associations between TSPO activation and stimulation of neurosteroid synthesis have been noted (Lacapère \& Papadopoulos, 2003; Le Goascogne et al., 2000). For example, Le Goascogne et al. (2000) have shown that TSPO activation in astrocytes promotes the synthesis of neurosteroids (Le Goascogne et al., 2000), which possess neurotrophic and neuroprotective activity (Le Goascogne et al., 2000) and are 
inhibitors of TNF production (Di Santo et al., 1996). A similar increase is obtained with anxiolytic benzodiazepines known to bind to both classes of benzodiazepine receptors (diazepam). On the contrary, ligands selective for the $\mathrm{GABA}_{\mathrm{A}}$ receptor (clonazepam) have no effect on steroid synthesis (Papadopoulos et al., 1992). On the other hand, Cascio et al. (2000) have shown a correlation among TSPO expression, steroid synthesis, myelination, and oligodendrocyte differentiation, thus reasserting the trophic function of TSPO in recovery from brain damage.

\section{b.2 Anti-apoptotic properties.}

The association of TSPO with the mitochondrial permeability transition pore suggests a role in the regulation of cell survival in microglia (McEnery et al., 1992). The participation of the TSPO in apoptotic processes has been demonstrated neither in MS patients nor in animal models of MS. However, studies that have induced overexpression of TSPO in cells different from those microglial ones suggest its implication in cell death regulation (Carayon et al., 1996; Everett \& McFadden, 2001; Johnston et al., 2001; Rey et al., 2000; Stoebner et al., 2001). Interestingly, forced TSPO overexpression in myxoma poxvirus-infected macrophages blocks apoptosis (Everett \& McFadden, 2001), in the same way that forced TSPO expression in neurons in vivo and Jurkat cells in vitro also protects these cells from apoptosis (Johnston et al., 2001; Stoebner et al., 2001). Likewise, it has been shown that TSPO upregulation in testicular Leydig cells (Rey et al., 2000) and in blood phagocytic cells (Carayon et al., 1996) preserves them from cytokine- and oxidant-induced cell death, respectively. TSPO expression in microglia may thus protect them from various toxins, thereby contributing to longer microglia life spans in the brain.

\section{c. Neurotoxic effects.}

A wealth of literature suggests that the TSPO overexpression, in addition to playing a protective role, can contribute to tissue destruction and disease progression (Block et al., 2007; Kreutzberg, 1996; Rothwell \& Hopkins, 1995). When microglia enter an overactivated state, they synthesize and release a battery of potent neurotoxins (including free radicals (Block et al., 2007; Chao et al., 1995a), NO (Chao et al., 1992), proteinases (Colton et al., 1993), eicosanoids (Heyes et al., 1996), and excitotoxins (Giulian et al., 1990), cytokines (IL-1 (Giulian et al., 1986), IL-6 (Righi et al., 1989), and TNFa (Chao et al., 1995b)), and chemokines (such as MIP-1a (Murphy et al., 1995), MIP$1 \beta$ (McManus et al., 1998), and MCP-1 (D'Aversa et al., 2002)) that cause neurotoxicity, influencing the viability and function of neurons and exacerbating neuronal injury. Two major possible neurotoxic secretion products of microglial cells are NO and TNF- $\alpha$ (Wilms et al., 2003). NO is neurotoxic due to inhibition of complex 1 and 2 of the respiratory chain. Moreover, it reacts with superoxide anion to generate peroxynitrite, a highly reactive molecule capable of oxidizing proteins, lipids, and DNA. The cytokine TNF-a is an important factor in the regulation of neuronal apoptotic cell death, which is expressed by astrocytes and microglial cells in brain lesions of MS patients (Wilms et al., 2003).

The inhibition of microglial activation by a pharmacological approach, using nonsteroidal anti-inflammatory drugs or minocycline, has been hypothesized to reduce neuronal damage in animal models of neurodegenerative diseases ( $\mathrm{Du}$ et al., 2001). Furthermore, activation of microglia also inhibits neurogenesis in the rat hippocampus, 
and hippocampal regeneration is restored by blocking microglial activation with either indomethacin (Monje et al., 2003) or minocycline (Ekdahl et al., 2003). These studies suggest that activation of microglia could perpetrate neurodegeneration through several mechanisms.

\section{Conclusion}

Animal models of MS are a very beneficial tool, which have led to a better understanding of MS. New clues to the pathogenesis of MS and new potential markers for the diagnosis and prognosis of MS have been gained from research in animal models. Likewise, they have helped in the development of therapeutic approaches that are currently being used.

The susceptibility to MS is modulated by interactions among many factors. In this context, it has been hypothesized that disease onset, progression, and relapses in MS are associated with stressful life events, and this alleged relation has been confirmed by sophisticated medical techniques. However, it is necessary to bear in mind that stressor characteristics are key factors in determining the effects of stress on MS symptom development.

Drugs known to affect the immune system have become the primary focus for managing MS. However, the most recent findings suggest that benzodiazepines might be an add-on option for MS treatment because they can modify the stress-induced manifestations of EAE by interacting with CBRs. Concretely, it has been demonstrated that alprazolam reduces the latent period and inflammatory lesions of the SNC and delays the onset of the disease. Several mechanisms have been hypothesized to explain the effects of this type of drugs, which influence hormonal, immune, endocrine, and/or inflammatory parameters associated with the HPA axis and the sympathetic branch of the ANS.

Recent evidence suggests that TSPOs might play a dual role in MS patients and perform neuroprotective and neurotoxic functions. On the other hand, because TSPO is dramatically up-regulated in MS, TSPO cellular expression is considered a reliable marker for diagnosis of the disease progression and of the therapeutic response.

\section{References}

Ackerman, K.D., Heyman, R., Rabin, B.S., Anderson, B.P., Houck, P.R., Frank, E., \& Baum, A. (2002). Stressful life events precede exacerbations of multiple sclerosis. Psychosomatic Medicine, Vol.64, No.6, pp. 916-920

Agnello, D., Carvelli, L., Muzio, V., Villa, P., Bottazzi, B., Polentarutti, N., Mennini, T., Mantovani, A., \& Ghezzi, P. (2000). Increased peripheral benzodiazepine binding sites and pentraxin 3 expression in the spinal cord during EAE: relation to inflammatory cytokines and modulation by dexamethasone and rolipram. Journal of Neuroimmunology, Vol.109, No.2, pp. 105-111

Alley, J., Khasabov, S., Simone, D., Beitz, A., Rodriguez, M., \& Njenga, M.K. (2003). More severe neurologic deficits in SJL/J male than female mice following Theiler's virusinduced CNS demyelination. Experimental Neurology, Vol.180, No.1, pp. 14-24

Anane, R., Geffard, M., Taxile, M., Bodet, D., Billaudel, B., Dulou, P.E., \& Veyret, B. (2003). Effects of GSM-900 microwaves on the experimental allergic encephalomyelitis (EAE) rat model of multiple sclerosis. Bioelectromagnetics, Vol.24, No.3, pp. 211-213 
Arroyo, R., Vila, C., \& Clissold, S. (2011). Retrospective observational study of the management of multiple sclerosis patients with resistant spasticity in Spain: the '5E' study. Expert Review of Pharmacoeconomics \& Outcomes Research, Vol.11, No.2, pp. 205-213

Arvat, E., Giordano, R., Grottoli, S., \& Ghigo, E. (2002). Benzodiazepines and anterior pituitary function. Journal of Endocrinological Investigation, Vol.25, No.8, pp. 735-747

Banati, R.B., Myers, R., \& Kreutzberg, G.W. (1997). PK ('peripheral benzodiazepine')-binding sites in the CNS indicate early and discrete brain lesions: microautoradiographic detection of [3H]PK11195 binding to activated microglia. Journal of Neurocytology, Vol.26, No.2, pp. 77-82

Banati, R.B., Goerres, G.W., Myers, R., Gunn, R.N., Turkheimer, F.E., Kreutzberg, G.W., Brooks, D.J., Jones, T., \& Duncan, J.S. (1999). [11C](R)-PK11195 positron emission tomography imaging of activated microglia in vivo in Rasmussen's encephalitis. Neurology, Vol.53, No.9, pp. 2199-2203

Banati, R.B., Newcombe, J., Gunn, R.N., Cagnin, A., Turkheimer, F., Heppner, F., Price, G., Wegner, F., Giovannoni, G., Miller, D.H., Perkin, G.D., Smith, T., Hewson, A.K., Bydder, G., Kreutzberg, G.W., Jones, T., Cuzner, M.L., \& Myers, R. (2000). The peripheral benzodiazepine binding site in the brain in multiple sclerosis: quantitative in vivo imaging of microglia as a measure of disease activity. Brain, Vo.123, No.11, pp. 2321-2337

Bernardini, R., Calogero, A.E., Ehrlich, Y.H., Brucke, T., Chrousos, G.P., \& Gold, P.W. (1989). The alkyl-ether phospholipid platelet-activating factor is a stimulator of the hypothalamic-pituitary-adrenal axis in the rat. Endocrinology, Vol.125, No.2, pp. 1067-1073

Bessler, H., Weizman, R., Gavish, M., Notti, I., \& Djaldetti, M. (1992). Immunomodulatory effect of peripheral benzodiazepine receptor ligands on human mononuclear cells. Journal of Neuroimmunology, Vol.38, No.1-2, pp. 19-25

Biber, K., Neumann, H., Inoue, K., \& Boddeke, H.W. (2007). Neuronal 'On' and 'Off' signals control microglia. Trends in Neurosciences, Vol.30, No.11, pp. 596-602

Bizzi, A., Ricci, M.R., Veneroni, E., Amato, M., \& Garattini, S. (1984). Benzodiazepine receptor antagonists reverse the effect of diazepam on plasma corticosterone in stressed rats. The Journal of Pharmacy and Pharmacology, Vol.36, No.2, pp. 134-135

Block, M.L., Zecca, L., \& Hong, J.S. (2007). Microglia-mediated neurotoxicity: uncovering the molecular mechanisms. Nature Reviews Neuroscience, Vol.8, No.1, pp. 57-69

Brown, R.F., Tennant, C.C., Dunn, S.M., \& Pollard, J.D. (2005). A review of stress-relapse interactions in multiple sclerosis: important features and stress-mediating and moderating variables. Multiple Sclerosis, Vol.11, No.4, pp. 477-484

Brown, R.F., Tennant, C.C., Sharrock, M., Hodgkinson, S., Dunn, S.M., \& Pollard, J.D. (2006). Relationship between stress and relapse in multiple sclerosis: Part I. Important features. Multiple Sclerosis, Vol.12, No.4, pp. 453-464

Bukilica, M., Djordjević, S., Marić, I., Dimitrijević, M., Marković, B.M., \& Janković, B.D. (1991). Stress-induced suppression of experimental allergic encephalomyelitis in the rat. The International Journal of Neuroscience, Vol.59, No.1-3, pp. 167-175

Bureau, J.F., Montagutelli, X., Bihl, F., Lefebvre, S., Guénet, J.L., \& Brahic, M. (1993). Mapping loci influencing the persistence of Theiler's virus in the murine central nervous system. Nature Genetics, Vol.5, No.1, pp. 87-91 
Bush, G., Fink, M., Petrides, G., Dowling, F., \& Francis, A. (1996). Catatonia. II. Treatment with lorazepam and electroconvulsive therapy. Acta Psychiatrica Scandinavica, Vol.93, No.2, pp. 137-143

Camins, A., Diez-Fernandez, C., Pujadas, E., Camarasa, J., \& Escubedo, E. (1995). A new aspect of the antiproliferative action of peripheral-type benzodiazepine receptor ligands. European Journal of Pharmacology, Vol.272, No.2-3, pp. 289-292

Campbell, T., Meagher, M.W., Sieve, A., Scott, B., Storts, R., Welsh, T.H., \& Welsh, C.J. (2001). The effects of restraint stress on the neuropathogenesis of Theiler's virus infection: I. Acute disease. Brain, Behavior, and Immunity, Vol.15, No.3, pp. 235-254

Carayon, P., Portier, M., Dussossoy, D., Bord, A., Petitprêtre, G., Canat, X., Le Fur, G., \& Casellas, P. (1996). Involvement of peripheral benzodiazepine receptors in the protection of hematopoietic cells against oxygen radical damage. Blood, Vol.87, No.8, pp. 3170-3178

Cascio, C., Brown, R.C., Liu, Y., Han, Z., Hales, D.B., \& Papadopoulos, V. (2000). Pathways of dehydroepiandrosterone formation in rat brain glia. The Journal of Steroid Biochemistry and Molecular Biology, Vol.75, No.2-3, pp. 177-186

Casellas, P., Galiegue, S., \& Basile, A.S. (2002). Peripheral benzodiazepine receptors and mitochondrial function. Neurochemistry International, Vol.40, No.6, pp. 475-486

Chan, A., Seguin, R., Magnus, T., Papadimitriou, C., Toyka, K.V., Antel, J.P., \& Gold, R. (2003). Phagocytosis of apoptotic inflammatory cells by microglia and its therapeutic implications: termination of CNS autoimmune inflammation and modulation by interferon-beta. Glia, Vol.43, No.3, pp. 231-242

Chandler, N., Jacobson, S., Esposito, P., Connolly, R., \& Theoharides, T.C. (2002). Acute stress shortens the time to onset of experimental allergic encephalomyelitis in SJL/J mice. Brain, Behavior, and Immunity, Vol.16, No.6, pp. 757-763

Chang, M.P., Castle, S.C., \& Norman, D.C. (1992). Mechanism of immunosuppressive effect of alprazolam: alprazolam suppresses T-cell proliferation by selectively inhibiting the production of IL2 but not acquisition of IL2 receptor. International Journal of Immunopharmacology, Vol.14, No.2, pp. 227-237

Chao, C.C., Hu, S., Molitor, T.W., Shaskan, E.G., \& Peterson, P.K. (1992). Activated microglia mediate neuronal cell injury via a nitric oxide mechanism. Journal of Immunology, Vol.149, No.8, pp. 2736-2741

Chao, C.C., Hu, S., \& Peterson, P.K. (1995a). Modulation of human microglial cell superoxide production by cytokines. Journal of Leukocyte Biology, Vol.58, No.1, pp. 65-70

Chao, C.C., Hu, S., Sheng, W.S., \& Peterson, P.K. (1995b). Tumor necrosis factor-alpha production by human fetal microglial cells: regulation by other cytokines. Developmental Neuroscience, Vol.17, No.2, pp. 97-105

Charcot, J.M. (1877). Lectures on diseases of the nervous system, New Sydenham Society, London

Choi, H.B., Khoo, C., Ryu, J.K., van Breemen, E., Kim, S.U., \& McLarnon, J.G. (2002). Inhibition of lipopolysaccharide-induced cyclooxygenase-2, tumor necrosis factoralpha and $[\mathrm{Ca} 2+]$ i responses in human microglia by the peripheral benzodiazepine receptor ligand PK11195. Journal of Neurochemistry, Vol.83, No.3, pp. 546-555 
Colton, C.A., Keri, J.E., Chen, W.T., \& Monsky, W.L. (1993). Protease production by cultured microglia: substrate gel analysis and immobilized matrix degradation. Journal of Neuroscience Research, Vol.35, No.3, pp. 297-304

Conway, E.L., Gundlach, A.L., \& Craven, J.A. (1998). Temporal changes in glial fibrillary acidic protein messenger RNA and [3H]PK11195 binding in relation to imidazoline-I2-receptor and alpha 2-adrenoceptor binding in the hippocampus following transient global forebrain ischaemia in the rat. Neuroscience, Vol.82, No.3, pp. $805-817$

Correa, S.G., Rodriguez-Galán, M.C., Rivero, V.E., \& Riera, C.M. (1998). Chronic varied stress modulates experimental autoimmune encephalomyelitis in Wistar rats. Brain, Behavior, and Immunity, Vol.12, No.2, pp. 134-148

Cosenza-Nashat, M., Zhao, M.L., Suh, H.S., Morgan, J., Natividad, R., Morgello, S., \& Lee, S.C. (2009). Expression of the translocator protein of $18 \mathrm{kDa}$ by microglia, macrophages and astrocytes based on immunohistochemical localization in abnormal human brain. Neuropathology and Applied Neurobiology, Vol.35, No.3, pp. 306-328

Costa, E., Auta, J., Guidotti, A., Korneyev, A., \& Romeo, E. The pharmacology of neurosteroidogenesis. The Journal of Steroid Biochemistry and Molecular Biology, Vol.49, No.4-6, pp. 385-389

Dal Canto, M.C., Melvold, R.W., Kim, B.S., \& Miller, S.D. (1995). Two models of multiple sclerosis: experimental allergic encephalomyelitis (EAE) and Theiler's murine encephalomyelitis virus (TMEV) infection. A pathological and immunological comparison. Microscopy Research and Technique, Vol.32, No.3, pp. 215-229

D'Aleo, G., Rifici, C., Kofler, M., Sessa, E., Saltuari, L., \& Bramanti, P. (2011). Seizure after intrathecal baclofen bolus in a multiple sclerosis patient treated.with oxcarbazepine. Neurological Sciences, Vol.32, No.2, pp. 293-295

Davalos, D., Grutzendler, J., Yang, G., Kim, J.V., Zuo, Y., Jung, S., Littman, D.R., Dustin, M.L., \& Gan, W.B. (2005). ATP mediates rapid microglial response to local brain injury in vivo. Nature Neuroscience, Vol.8, No.6, pp. 752-758

D'Aversa, T.G., Weidenheim, K.M., \& Berman, J.W. (2002). CD40-CD40L interactions induce chemokine expression by human microglia: implications for human immunodeficiency virus encephalitis and multiple sclerosis. The American Journal of Pathology, Vol.160, No.2, pp. 559-567

Debruyne, J.C., Versijpt, J., Van Laere, K.J., De Vos, F., Keppens, J., Strijckmans, K., Achten, E., Slegers, G., Dierckx, R.A., Korf, J., \& De Reuck, J.L. (2003). PET visualization of microglia in multiple sclerosis patients using [11C]PK11195. European Journal of Neurology, Vol.10, No.3, pp. 257-264

Del Rey, A., Klusman, I., \& Besedovsky, H.O. (1998). Cytokines mediate protective stimulation of glucocorticoid output during autoimmunity: involvement of IL-1. The American Journal of Physiology, Vol.275, No.4, pp. R1146-1151

Di Santo, E., Sironi, M., Mennini, T., Zinetti, M., Savoldi, G., Di Lorenzo, D., \& Ghezzi, P. (1996). A glucocorticoid receptor-independent mechanism for neurosteroid inhibition of tumor necrosis factor production. European Journal of Pharmacology, Vol.299, No.1-3, pp. 179-186 
Dittel, B.N., Visintin, I., Merchant, R.M., \& Janeway, C.A. Jr. (1999). Presentation of the self antigen myelin basic protein by dendritic cells leads to experimental autoimmune encephalomyelitis. Journal of Immunology, Vol.163, No.1, pp. 32-39

Dimitrijević, M., Laban, O., von Hoersten, S., Marković, B.M., \& Janković, B.D. (1994). Neonatal sound stress and development of experimental allergic encephalomyelitis in Lewis and DA rats. The International Journal of Neuroscience, Vol.78, No.1-2, pp. 135-143

Dowdell, K.C., Gienapp, I.E., Stuckman, S., Wardrop, R.M., \& Whitacre, C.C. (1999). Neuroendocrine modulation of chronic relapsing experimental autoimmune encephalomyelitis: a critical role for the hypothalamic-pituitary-adrenal axis. Journal of Neuroimmunology, Vol.100, No.1-2, pp. 243-251

Du, Y., Ma, Z., Lin, S., Dodel, R.C., Gao, F., Bales, K.R., Triarhou, L.C., Chernet, E., Perry, K.W., Nelson, D.L., Luecke, S., Phebus, L.A., Bymaster, F.P., \& Paul, S.M. (2001). Minocycline prevents nigrostriatal dopaminergic neurodegeneration in the MPTP model of Parkinson's disease. Proceedings of the Society for Experimental Biology and Medicine, Vol.98, No.25, pp. 14669-14674

Ekdahl, C.T., Claasen, J.H., Bonde, S., Kokaia, Z., \& Lindvall, O. (2003). Inflammation is detrimental for neurogenesis in adult brain. Proceedings of the Society for Experimental Biology and Medicine, Vol.100, No.23, pp. 13632-13637

Ercolini, A.M., \& Miller, S.D. (2006). Mechanisms of immunopathology in murine models of central nervous system demyelinating disease. Journal of Immunology, Vol.176, No.6, pp. 3293-3298

Everett, H., \& McFadden, G. (2001). Viruses and apoptosis: meddling with mitochondria. Virology, Vol.288, No.1, pp. 1-7

Fetler, L., \& Amigorena, S. (2005). Brain Under Surveillance: The Microglia Patrol. Science, Vol.309, No.5733, pp. 392-393

Fife, B.T., Huffnagle, G.B., Kuziel, W.A., \& Karpus, W.J. (2000). CC chemokine receptor 2 is critical for induction of experimental autoimmune encephalomyelitis. The Journal of Experimental Medicine, Vol.192, No.6, pp. 899-905

Franklin, G.M., Nelson, L.M., Heaton, R.K., Burks, J.S., \& Thompson, D.S. (1988). Stress and its relationship to acute exacerbations in multiple sclerosis (MS). The Journal of Neurological Rehabilitation, Vol.2, No.1, pp. 7-11

Freire-Garabal, M., Belmonte, A., \& Suárez-Quintanilla, J. (1991). Effects of buspirone on the immunosuppressive response to stress in mice. Archives Internationales de Pharmacodynamie et de Thérapie, Vol.314, No.1-2, pp. 160-168

Freire-Garabal, M., Núñez, M.J., Balboa, J.L., González-Bahillo, J., \& Belmonte, A. (1993a). Effects of midazolam on the activity of phagocytosis in mice submitted to surgical stress. Pharmacology, Biochemistry and Behavior, Vol.46, No.3, pp. 605-608

Freire-Garabal, M., Núñez, M.J., Fernández-Rial, J.C., Couceiro, J., García-Vallejo, L., \& ReyMéndez, M. (1993b). Phagocytic activity in stressed mice: effects of alprazolam. Research in Immunology, Vol.144, No.5, pp. 311-316

Freire-Garabal, M., Núñez, M.J., Losada, C., Pereiro, D., Riveiro, M.P., González-Patiño, E., Mayán, J.M., \& Rey-Mendez, M. (1997). Effects of fluoxetine on the immunosuppressive response to stress in mice. Life Sciences, Vol.60, No.26, pp. PL403-413 
Friedman, E.M., \& Lawrence, D.A. (2002). Environmental stress mediates changes in neuroimmunological interactions. Toxicological Sciences, Vol.67, No.1, pp. 4-10

Friedmann, A., \& Lorch, Y. (1985). Theiler's virus infection: a model for multiple sclerosis. Progress in Medical Virology, Vol.31, pp. 43-83

Fukui, Y., Sudo, N., Yu, X.N., Nukina, H., Sogawa, H., \& Kubo, C. (1997). The restraint stress-induced reduction in lymphocyte cell number in lymphoid organs correlates with the suppression of in vivo antibody production. Journal of Neuroimmunology, Vol.79, No.2, pp. 211-217

Gaillard, R.C., \& Spinedi, E. (1998). Sex- and stress-steroids interactions and the immune system: evidence for a neuroendocrine-immunological sexual dimorphism. Domestic Animal Endocrinology, Vol.15, No.5, pp. 345-352

Gardier, A.M., Guiard, B.P., Guilloux, J.P., Repérant, C., Coudoré, F., \& David, D.J. (2009). Interest of using genetically manipulated mice as models of depression to evaluate antidepressant drugs activity: a review. Fundamental \& Clinical Pharmacology, Vol.23, No.1, pp. 23-42

Gasperini, C., Grasso, M.G., Fiorelli, M., Millefiorini, E., Morino, S., Anzini, A., Colleluori, A., Salvetti, M., Buttinelli, C., \& Pozzilli, C. (1995). A controlled study of potential risk factors preceding exacerbation in multiple sclerosis. Journal of Neurology, Neurosurgery, and Psychiatry, Vol.59, No.3, pp. 303-305

Gavish, M., Bachman, I., Shoukrun, R., Katz, Y., Veenman, L., Weisinger, G., \& Weizman, A. (1999). Enigma of the peripheral benzodiazepine receptor. Pharmacologica Reviews, Vol.51, No.4, pp. 629-650

Geczy, C.L., Roberts, I.M., Meyer, P., \& Bernard, C.C. (1984). Susceptibility and resistance to experimental autoimmune encephalomyelitis and neuritis in the guinea pig correlate with the induction of procoagulant and anticoagulant activities. Journal of Immunology, Vol.133, No.6, pp. 3026-3036

Genain, C.P., \& Hauser, S.L. (2001). Experimental allergic encephalomyelitis in the New World monkey Callithrix jacchus. Immunological Reviews, Vol.183, No.1, pp. 159-172

Giulian, D., Baker, T.J., Shih, L.C., \& Lachman, L.B. (1986). Interleukin 1 of the central nervous system is produced by ameboid microglia. The Journal of Experimental Medicine, Vol.164, No.2, pp. 594-604

Giulian, D., Vaca, K., \& Noonan, C.A. (1990). Secretion of neurotoxins by mononuclear phagocytes infected with HIV-1. Science, Vol.250, No.4987, pp. 1593-1596

Glaser, R., \& Kiecolt-Glaser, J.K. (2005). Stress-induced immune dysfunction: implications for health. Nature Reviews. Immunology, Vol.5, No.3, pp. 243-251

Glezer, I., Simard, A.R., \& Rivest, S. (2007). Neuroprotective role of the innate immune system by microglia. Neuroscience, Vol.147, No.4, pp. 867-883

Godbout, J.P., \& Glaser, R. (2006). Stress-induced immune dysregulation: implications for wound healing, infectious disease and cancer. Journal of Neuroimmune Pharmacology, Vol.1, No.4, pp. 421-427

Golan, D., Somer, E., Dishon, S., Cuzin-Disegni, L., \& Miller, A. (2008). Impact of exposure to war stress on exacerbations of multiple sclerosis. Annals of Neurology, Vol.64, No.2, pp. $143-148$

Gold, R., Linington, C., \& Lassmann, H. (2006). Understanding pathogenesis and therapy of multiple sclerosis via animal models: 70 years of merits and culprits in 
experimental autoimmune encephalomyelitis research. Brain, Vol.129, No.8, pp. 1953-1971

Gold, S.M., Mohr, D.C., Huitinga, I., Flachenecker, P., Sternberg, E.M., \& Heesen, C. (2005). The role of stress-response systems for the pathogenesis and progression of MS. Trends in Immunology, Vol.26, No.12, pp. 644-652

Goodin, D.S. (2008). The impact of war-stress on MS exacerbations. Annals of Neurology, Vol.64, No.2, pp. 114-115

Goodin, D.S., Ebers, G.C., Johnson, K.P., Rodriguez, M., Sibley, W.A., \& Wolinsky, J.S. (1999). The relationship of MS to physical trauma and psychological stress: report of the Therapeutics and Technology Assessment Subcommittee of the American Academy of Neurology. Neurology, Vol.52, No.9, pp. 1737-1745

Grant, I., Brown, G.W., Harris, T., McDonald, W.I., Patterson, T., \& Trimble, M.R. (1989). Severely threatening events and marked life difficulties preceding onset or exacerbation of multiple sclerosis. Journal of Neurology, Neurosurgery and Psychiatry, Vol.52, No.1, pp. 8-13

Greenwood, J., Steinman, L., \& Zamvil, S.S. (2006). Statin therapy and autoimmune disease: from protein prenylation to immunomodulation. Nature Reviews. Immunology, Vol.6, No.5, pp. 358-370

Griffin, A.C., Lo, W.D., Wolny, A.C., \& Whitacre, C.C. (1993). Suppression of experimental autoimmune encephalomyelitis by restraint stress: sex differences. Journal of Neuroimmunology, Vol.44, No.1, pp. 103-116

Guillemin, G.J., \& Brew, B.J. (2004). Microglia, macrophages, perivascular macrophages, and pericytes: a review of function and identification. Journal of Leukocyte Biology, Vol.75, No.3, pp. 388-397

Heesen, C., Gold, S.M., Huitinga, I., \& Reul, J.M. (2007). Stress and hypothalamic-pituitaryadrenal axis function in experimental autoimmune encephalomyelitis and multiple sclerosis - a review. Psychoneuroendocrinology, Vol.32, No.6, pp. 604-618

Heiss, W.D., \& Herholz, K. (2006). Brain receptor imaging. Journal of Nuclear Medicine, Vol.47, No.2, pp. 302-312

Heyes, M.P., Achim, C.L., Wiley, C.A., Major, E.O., Saito, K., \& Markey, S.P. (1996). Human microglia convert l-tryptophan into the neurotoxin quinolinic acid. The Biochemical Journal, Vol.320 (Pt 2), pp. 595-597

Hill, K.E., Pigmans, M., Fujinami, R.S., \& Rose, J.W. (1998). Gender variations in early Theiler's virus induced demyelinating disease: differential susceptibility and effects of IL-4, IL-10 and combined IL-4 with IL-10. Journal of Neuroimmunology, Vol.85, No.1, pp. 44-51

Hirsch, J.D., Beyer, C.F., Malkowitz, L., Beer, B., \& Blume, A.J. (1989). Mitochondrial benzodiazepine receptors mediate inhibition of mitochondrial respiratory control. Molecular Pharmacology, Vol.35, No.1, pp. 157-163

Hirtz, D., Thurman, D.J., Gwinn-Hardy, K., Mohamed, M., Chaudhuri, A.R., \& Zalutsky, R. (2007). How common are the "common" neurologic disorders?. Neurology, Vol.68, No.5, pp. 326-337

Hung, Y.Y., \& Huang, T.L. (2007). Lorazepam and diazepam for relieving catatonic features in multiple sclerosis. Progress in Neuropsychopharmacology \& Biological Psychiatry, Vol.31, No.7, pp. 1537-1538 
Inoue, A., Koh, C.S., Shimada, K., Yanagisawa, N., \& Yoshimura, K. (1996). Suppression of cell-transferred experimental autoimmune encephalomyelitis in defibrinated Lewis rats. Journal of Neuroimmunology, Vol.71, No.1-2, pp. 131-137

Izikson, L., Klein, R.S., Charo, I.F., Weiner, H.L., \& Luster, A.D. (2000). Resistance to experimental autoimmune encephalomyelitis in mice lacking the CC chemokine receptor (CCR)2. The Journal of Experimental Medicine, Vol.192, No.7, pp. 1075-80

Jayakumar, A.R., Panickar, K.S., \& Norenberg, M.D. (2002). Effects on free radical generation by ligands of the peripheral benzodiazepine receptor in cultured neural cells. Journal of Neurochemistry, Vol.83, No.5, pp. 1226-1234

Johnson, R.R., Storts, R., Welsh, T.H. Jr., Welsh, C.J., \& Meagher, M.W. (2004). Social stress alters the severity of acute Theiler's virus infection. Journal of Neuroimmunology, Vol.148, No.1-2, pp. 74-85

Johnson, R.R., Prentice, T.W., Bridegam, P., Young, C.R., Steelman, A.J., Welsh, T.H., Welsh, C.J., \& Meagher, M.W. (2006). Social stress alters the severity and onset of the chronic phase of Theiler's virus infection. Journal of Neuroimmunology, Vol.175, No.1-2, pp. 39-51

Johnston, C., Jiang, W., Chu, T., \& Levine, B. (2001). Identification of genes involved in the host response to neurovirulent alphavirus infection. Journal of Virology, Vol.75, No.21, pp. 10431-10445

Juedes, A.E., Hjelmström, P., Bergman, C.M., Neild, A.L., \& Ruddle, N.H. (2000). Kinetics and cellular origin of cytokines in the central nervous system: insight into mechanisms of myelin oligodendrocyte glycoprotein-induced experimental autoimmune encephalomyelitis. Journal of Immunology, Vol.164, No.1, pp. 419-426

Junck, L., Olson, J.M., Ciliax, B.J., Koeppe, R.A., Watkins, G.L., Jewett, D.M., McKeever, P.E., Wieland, D.M., Kilbourn, M.R., Starosta-Rubinstein, S., Mancini, W.R., Kuhl, D.E., Greenberg, H.S., \& Young, A.B. (1989). PET imaging of human gliomas with ligands for the peripheral benzodiazepine binding site. Annals of Neurology, Vol.26, No.6, pp. 752-758

Kappel, C.A., Melvold, R.W., \& Kim, B.S. (1990). Influence of sex on susceptibility in the Theiler's murine encephalomyelitis virus model for multiple sclerosis. Journal of Neuroimmunology, Vol.29, No.1-3, pp. 15-19

Karpus, W.J., \& Kennedy, K.J. (1997). MIP-1alpha and MCP-1 differentially regulate acute and relapsing autoimmune encephalomyelitis as well as Th1/Th2 lymphocyte differentiation. Journal of Leukocyte Biology, Vol.62, No.5, pp. 681-687

Karpus, W.J., \& Ransohoff, R.M. (1998). Chemokine regulation of experimental autoimmune encephalomyelitis: temporal and spatial expression patterns govern disease pathogenesis. Journal of Neuroimmunology, Vol.161, No.6, pp. 2667-2671

Kornecki, E., Ehrlich, Y.H., \& Lenox, R.H. (1984). Platelet-activating factor-induced aggregation of human platelets specifically inhibited by triazolobenzodiazepines. Science, Vol.226, No.4681, pp. 1454-1456

Kornecki, E., Lenox, R.H., Hardwick, D.H., Bergdahl, J.A., \& Ehrlich, Y.H. (1987). Interactions of the alkyl-ether-phospholipid, platelet activating factor (PAF) with platelets, neural cells, and the psychotropic drugs triazolobenzodiazepines. Advances in Experimental Medicine and Biology, Vol.221, pp. 477-488

Kreutzberg, G.W. (1996). Microglia: a sensor for pathological events in the CNS. Trends in Neurosciences, Vol.19, No.8, pp. 312-318 
Kuhlmann, A.C., \& Guilarte, T.R. (2000). Cellular and subcellular localization of peripheral benzodiazepine receptors after trimethyltin neurotoxicity. Journal of Neurochemistry, Vol.74, No.4, pp. 1694-1704

Kuroda, Y., Mori, T., \& Hori, T. (1994). Restraint stress suppresses experimental allergic encephalomyelitis in Lewis rats. Brain Research Bulletin, Vol.34, No.1, pp. 15-17

Laban, O., Dimitrijević, M., von Hoersten, S., Marković, B.M., \& Janković, B.D. (1995a). Experimental allergic encephalomyelitis in adult DA rats subjected to neonatal handling or gentling. Brain Research, Vol.676, No.1, pp. 133-140

Laban, O., Marković, B.M., Dimitrijević, M., \& Janković, B.D. (1995b). Maternal deprivation and early weaning modulate experimental allergic encephalomyelitis in the rat. Brain, Behavior, and Immunity, Vol.9, No.1, pp. 9-19

Lacapère, J.J., \& Papadopoulos, V. (2003). Peripheral-type benzodiazepine receptor: structure and function of a cholesterol-binding protein in steroid and bile acid biosynthesis. Steroids, Vol.68, No.7-8, pp. 569-585

Lacor, P., Gandolfo, P., Tonon, M.C., Brault, E., Dalibert, I., Schumacher, M., Benavides, J., \& Ferzaz, B. (1999). Regulation of the expression of peripheral benzodiazepine receptors and their endogenous ligands during rat sciatic nerve degeneration and regeneration: a role for PBR in neurosteroidogenesis. Brain Research, Vol.815, No.1, pp. $70-80$

Lavi, E., \& Constantinescu, C.S. (2005). Experimental Models of Multiple Sclerosis, Springer Verlag, ISBN 0-387-25517-6, New York

Le Goascogne, C., Eychenne, B., Tonon, M.C., Lachapelle, F., Baumann, N., \& Robel, P. (2000). Neurosteroid progesterone is up-regulated in the brain of jimpy and shiverer mice. Glia, Vol.29, No.1, pp. 14-24

Le Page, C., Ferry, A., \& Rieu, M. (1994). Effect of muscular exercise on chronic relapsing experimental autoimmune encephalomyelitis. Journal of Applied Physiology, Vol.77, No.5, pp. 2341-2347

Le Page, C., Bourdoulous, S., Béraud, E., Couraud, P.O., Rieu, M., \& Ferry, A. (1996). Effect of physical exercise on adoptive experimental auto-immune encephalomyelitis in rats. European Journal of Applied Physiology and Occupational Physiology, Vol.73, No.12, pp. 130-135

Lenfant, M., Haumont, J., \& Zavala, F. (1986). In vivo immunomodulating activity of PK 1195, a structurally unrelated ligand for "peripheral" benzodiazepine binding sites-I. Potentiation in mice of the humoral response to sheep red blood cells. International Journal of Immunopharmacology, Vol.8, No.7, pp. 825-828

Levine, S., \& Saltzman, A. (1987). Nonspecific stress prevents relapses of experimental allergic encephalomyelitis in rats. Brain, Behavior, and Immunity, Vol.1, No.4, pp. 336-341

Levine, S., Strebel, R., Wenk, E.J., \& Harman, P.J. (1962). Suppression of experimental allergic encephalomyelitis by stress. Proceedings of the Society for Experimental Biology and Medicine, Vol.109, pp. 294-298

Li, J., Johansen, C., Brønnum-Hansen, H., Stenager, E., Koch-Henriksen, N., \& Olsen, J. (2004). The risk of multiple sclerosis in bereaved parents: A nationwide cohort study in Denmark. Neurology, Vol.62, No.5, pp. 726-729

Libbey, J.E., \& Fujinami, R.S. (2011). Experimental autoimmune encephalomyelitis as a testing paradigm for adjuvants and vaccines. Vaccine, Vol.29, No.17, pp. 3356-3362 
Lipton, H.L. (1975). Theiler's virus infection in mice: an unusual biphasic disease process leading to demyelination. Infection and Immunity, Vol.11, No.5, pp. 1147-1155

Loers, G., Aboul-Enein, F., Bartsch, U., Lassmann, H., \& Schachner, M. (2004). Comparison of myelin, axon, lipid, and immunopathology in the central nervous system of differentially myelin-compromised mutant mice: a morphological and biochemical study. Molecular and Cellular Neurosciences, Vol.27, No.2, pp. 175-189

MacPhee, I.A., Antoni, F.A., \& Mason, D.W. (1989). Spontaneous recovery of rats from experimental allergic encephalomyelitis is dependent on regulation of the immune system by endogenous adrenal corticosteroids. The Journal of Experimental Medicine, Vol.169, No.2, pp. 431-445

Maeda, J., Suhara, T., Zhang, M.R., Okauchi, T., Yasuno, F., Ikoma, Y., Inaji, M., Nagai, Y., Takano, A., Obayashi, S., \& Suzuki, K. (2004). Novel peripheral benzodiazepine receptor ligand [11C]DAA1106 for PET: an imaging tool for glial cells in the brain. Synapse, Vol.52, No.4, pp. 283-291

Marino, F., Cattaneo, S., Cosentino, M., Rasini, E., Di Grazia, L., Fietta, A.M., Lecchini, S., \& Frigo, G. (2001). Diazepam stimulates migration and phagocytosis of human neutrophils: possible contribution of peripheral-type benzodiazepine receptors and intracellular calcium. Pharmacology, Vol.63, No.1, pp. 42-49

Martinelli, V. (2000). Trauma, stress and multiple sclerosis. Neurological Sciences, Vol.21, No.4, pp. S849-852

Masood, A., Banerjee, B., Vijayan, V.K., \& Ray, A. (2003). Modulation of stress-induced neurobehavioral changes by nitric oxide in rats. European Journal of Pharmacology, Vol.458, No.1-2, pp. 135-139

Matsushima, G.K., \& Morell, P. (2001). The neurotoxicant, cuprizone, as a model to study demyelination and remyelination in the central nervous system. Brain Pathology, Vol.11, No.1, pp. 107-116

Mattner, F., Katsifis, A., Staykova, M., Ballantyne, P., \& Willenborg, D.O. (2005). Evaluation of a radiolabelled peripheral benzodiazepine receptor ligand in the central nervous system inflammation of experimental autoimmune encephalomyelitis: a possible probe for imaging multiple sclerosis. European Journal of Nuclear Medicine and Molecular Imaging, Vol.32, No.5, pp. 557-563

McEnery, M.W., Snowman, A.M., Trifiletti, R.R., \& Snyder, S.H. (1992). Isolation of the mitochondrial benzodiazepine receptor: association with the voltage-dependent anion channel and the adenine nucleotide carrier. Proceedings of the National Academy of Sciences of the United States of America, Vol.89, No.8, pp. 3170-3174

McManus, C.M., Brosnan, C.F., \& Berman, J.W. (1998). Cytokine induction of MIP-1 alpha and MIP-1 beta in human fetal microglia. Journal of Immunology, Vol.160, No.3, pp. 1449-1455

McQualter, J.L., \& Bernard, C.C. (2007). Multiple sclerosis: a battle between destruction and repair. Journal of Neurochemistry, Vol.100, No.2, pp. 295-306

Meagher, M.W., Johnson, R.R., Young, E.E., Vichaya, E.G., Lunt, S., Hardin, E.A., Connor, M.A., \& Welsh, C.J. (2007). Interleukin-6 as a mechanism for the adverse effects of social stress on acute Theiler's virus infection. Brain, Behavior, and Immunity, Vol.21, No.8, pp. 1083-1095 
Meythaler, J.M., Tuel, S.M., \& Cross, L.L. (1991). Spinal cord seizures: a possible cause of isolated myoclonic activity in traumatic spinal cord injury: case report. Paraplegia, Vol.29, No.8, pp. 557-560

Mi, W., Belyavskyi, M., Johnson, R.R., Sieve, A.N., Storts, R., Meagher, M.W., \& Welsh, C.J. (2004). Alterations in chemokine expression following Theiler's virus infection and restraint stress. Journal of Neuroimmunology, Vol.151, No.1-2, pp. 103-115

Mi, W., Prentice, T.W., Young, C.R., Johnson, R.R., Sieve, A.N., Meagher, M.W., \& Welsh, C.J. (2006). Restraint stress decreases virus-induced pro-inflammatory cytokine mRNA expression during acute Theiler's virus infection. Journal of Neuroimmunology, Vol.178, No.1-2, pp. 49-61

Mohr, D.C., Goodkin, D.E., Bacchetti, P., Boudewyn, A.C., Huang, L., Marrietta, P., Cheuk, W., \& Dee, B. (2000). Psychological stress and the subsequent appearance of new brain MRI lesions in MS. Neurology, Vol.55, No.1, pp. 55-61

Mohr, D.C., Hart, S.L., Julian, L., Cox, D., \& Pelletier, D. (2004). Association between stressful life events and exacerbation in multiple sclerosis: a meta-analysis. BMJ, Vol.328, No.7442, pp. 731-735

Monje, M.L., Toda, H., \& Palmer, T.D. (2003). Inflammatory blockade restores adult hippocampal neurogenesis. Science, Vol.302, No.5651, pp. 1760-1765

Monteyne, P., Bureau, J.F., \& Brahic, M. (1997). The infection of mouse by Theiler's virus: from genetics to immunology. Immunological Reviews, Vol.159, No.1, pp. 163-176

Morgan, D., Gordon, M.N., Tan, J., Wilcock, D., \& Rojiani, A.M. (2005). Dynamic complexity of the microglial activation response in transgenic models of amyloid deposition: implications for Alzheimer therapeutics. Journal of Neuropathology and Experimental Neurology, Vol.64, No.9, pp. 743-753

Murphy, G.M. Jr., Jia, X.C., Song, Y., Ong, E., Shrivastava, R., Bocchini, V., Lee, Y.L., \& Eng, L.F. (1995). Macrophage inflammatory protein 1-alpha mRNA expression in an immortalized microglial cell line and cortical astrocyte cultures. Journal of Neuroscience Research, Vol.40, No.6, pp. 755-763

Ng, D.S., \& Wong, K. (1988). Specific binding of platelet-activating factor (PAF) by human peripheral blood mononuclear leukocytes. Biochemical and Biophysical Research Communications, Vol.155, No.1, pp. 311-316

Nimmerjahn, A., Kirchhoff, F., \& Helmchen, F. (2005). Resting microglial cells are highly dynamic surveillants of brain parenchyma in vivo. Science, Vol.308, No.5726, pp. 1314-1318

Nisipeanu, P., \& Korczyn, A.D. (1993). Psychological stress as risk factor for exacerbations in multiple sclerosis. Neurology, Vol.43, No.7, pp. 1311-1312

Noseworthy, J.H., Lucchinetti, C., Rodriguez, M., \& Weinshenker, B.G. (2000). Multiple sclerosis. The New England Journal of Medicine, Vol.343, No.13, pp. 938-952

Núñez, M.J., Riveiro, M.P., Varela, M., Liñares, D., Lopez, P., Maña, P., MartinezBahamonde, F., Núñez, L., Mayan, J.M., Rey-Mendez, M., \& Freire-Garabal, M. (1998). Effects of nefazodone on delayed type hypersensitivity response in stressed mice. Research Communications in Biological Psychology and Psychiatry, Vol.23, No.1-2, pp. $19-27$

Núñez, M.J., Balboa, J., Rodrigo, E., Brenlla, J., González-Peteiro, M., \& Freire-Garabal, M. (2006). Effects of fluoxetine on cellular immune response in stressed mice. Neuroscience Letters, Vol.396, No.3, pp. 247-251 
Núñez-Iglesias, M.J., Novío, S., Almeida-Dias, A., \& Freire-Garabal, M. (2010). Inhibitory effects of alprazolam on the development of acute experimental autoimmune encephalomyelitis in stressed rats. Pharmacology, Biochemistry, and Behavior, Vol.97, No.2, pp. 350-356

Oda, T., Ueda, A., Shimizu, N., Handa, H., \& Kasahara, T. (2002). Suppression of monocyte chemoattractant protein 1, but not IL-8, by alprazolam: effect of alprazolam on c$\mathrm{Rel} / \mathrm{p} 65$ and c-Rel/p50 binding to the monocyte chemoattractant protein 1 promoter region. Journal of Immunology, Vol.169, No.6, pp. 3329-3335

Oleszak, E.L., Chang, J.R., Friedman, H., Katsetos, C.D., \& Platsoucas, C.D. (2004). Theiler's virus infection: a model for multiple sclerosis. Clinical Microbiology Reviews, Vol.17, No.1, pp. 174-207

Olson, J.M., Ciliax, B.J., Mancini, W.R., \& Young, A.B. (1988). Presence of peripheral-type benzodiazepine binding sites on human erythrocyte membranes. European Journal of Pharmacology, Vol.152, No.1-2, pp. 47-53

Owens, M.J., Bissette, G., \& Nemeroff, C.B. (1989). Acute effects of alprazolam and adinazolam on the concentrations of corticotropin-releasing factor in the rat brain. Synapse, Vol.4, No.3, pp. 196-202

Owens T. (2006). Animal models for multiple sclerosis. Advances in Neurology, Vol.98, No.1, pp. 77-89

Owhashi, M., Shouzui, Y., \& Arita, H. (1997). Stress down-regulates experimental allergic encephalomyelitis (EAE) but permits activation and localization of autoreactive $\mathrm{V}$ beta 8.2+ T cells. The International Journal of Neuroscience, Vol.89, No.3-4, pp. 177-188

Pahan, K. (2010). Neuroimmune pharmacological control of EAE. Journal of Neuroimmune Pharmacology, Vol.5, No.2, pp. 165-168

Papadopoulos, V., Guarneri, P., Kreuger, K.E., Guidotti, A., \& Costa, E. (1992). Pregnenolone biosynthesis in C6-2B glioma cell mitochondria: regulation by a mitochondrial diazepam binding inhibitor receptor. Proceedings of the National Academy of Sciences of the United States of America, Vol.89, No.11, pp. 5113-5117

Papadopoulos, V., Amri, H., Li, H., Boujrad, N., Vidic, B., \& Garnier, M. (1997). Targeted disruption of the peripheral-type benzodiazepine receptor gene inhibits steroidogenesis in the R2C Leydig tumor cell line. The Journal of Biological Chemistry, Vol.272, No.51, pp. 32129-32135

Papadopoulos, V., Baraldi, M., Guilarte, T.R., Knudsen, T.B., Lacapère, J.J., Lindemann, P., Norenberg, M.D., Nutt, D., Weizman, A., Zhang, M.R., \& Gavish, M. (2006a). Translocator protein $(18 \mathrm{kDa})$ : new nomenclature for the peripheral-type benzodiazepine receptor based on its structure and molecular function. Trends in Pharmacological Sciences, Vol.27, No.8, pp. 402-409

Papadopoulos, V., Lecanu, L., Brown, R.C., Han, Z., \& Yao, Z.X. (2006b). Peripheral-type benzodiazepine receptor in neurosteroid biosynthesis, neuropathology and neurological disorders. Neuroscience, Vol.138, No.3, pp. 749-756

Patte, C., Gandolfo, P., Leprince, J., Thoumas, J.L., Fontaine, M., Vaudry, H., \& Tonon, M.C. (1999). GABA inhibits endozepine release from cultured rat astrocytes. Glia, Vol.25, No.4, pp. 404-411

Pawlikowski, M. (1993). Immunomodulating effects of peripherally acting benzodiazepines, In: Peripheral benzodiazepine receptors, E. Giesen-Crouse, (Ed), 125-135, Academic Press, London 
Pérez-Nievas, B.G., García-Bueno, B., Madrigal, J.L., \& Leza, J.C. (2010). Chronic immobilisation stress ameliorates clinical score and neuroinflammation in a MOGinduced EAE in Dark Agouti rats: mechanisms implicated. Journal of Neuroinflammation, Vol.7, pp. 60-72

Pratt, R.T. (1951). An investigation of the psychiatric aspects of disseminated sclerosis. Journal of Neurology, Neurosurgery, and Psychiatry, Vol.14, No.4, pp. 326-335

Ransohoff, R.M. (1999). Mechanisms of inflammation in MS tissue: adhesion molecules and chemokines. Journal of Neuroimmunology, Vol.98, No.1, pp. 57-68

Rey, C., Mauduit, C., Naureils, O., Benahmed, M., Louisot, P., \& Gasnier, F. (2000). Upregulation of mitochondrial peripheral benzodiazepine receptor expression by tumor necrosis factor alpha in testicular leydig cells. Possible involvement in cell survival. Biochemical Pharmacology, Vol.60, No.11, pp. 1639-1646

Righi, M., Mori, L., De Libero, G., Sironi, M., Biondi, A., Mantovani, A., Donini, S.D., \& Ricciardi-Castagnoli, P. (1989). Monokine production by microglial cell clones. European Journal of Immunology, Vol.19, No.8, pp. 1443-1448

Rock, R.B., \& Peterson, P.K. (2006). Microglia as a pharmacological target in infectious and inflammatory diseases of the brain. Journal of Neuroimmune Pharmacology, Vol.1, No.2, pp. 117-126

Rode, G., Maupas, E., Luaute, J., Courtois-Jacquin, S., \& Boisson, D. (2003). [Medical treatment of spasticity]. Neurochirurgie, Vol.49, No.2-3, pp. 247-255

Rodriguez, M., Kenny, J.J., Thiemann, R.L., \& Woloschak, G.E. (1990). Theiler's virusinduced demyelination in mice immunosuppressed with anti-IgM and in mice expressing the xid gene. Microbial Pathogenesis, Vol.8, No.1, pp. 23-35

Rothwell, N.J., \& Hopkins, S.J. (1995). Cytokines and the nervous system II: Actions and mechanisms of action. Trends in Neurosciences, Vol.18, No.3, pp. 130-136

Ruff, M.R., Pert, C.B., Weber, R.J., Wahl, L.M., Wahl, S.M., \& Paul, S.M. (1985). Benzodiazepine receptor-mediated chemotaxis of human monocytes. Science, Vol.229, No.4719, pp. 1281-1283

Ryu, J.K., Choi, H.B., \& McLarnon, J.G. (2005). Peripheral benzodiazepine receptor ligand PK11195 reduces microglial activation and neuronal death in quinolinic acidinjected rat striatum. Neurobiology of Disease, Vol.20, No.2, pp. 550-561

Schwartz-Bloom, R.D., Miller, K.A., Evenson, D.A., Crain, B.J., \& Nadler, J.V. (2000). Benzodiazepines protect hippocampal neurons from degeneration after transient cerebral ischemia: an ultrastructural study. Neuroscience, Vol.98, No.3, pp. 471-484

Sela, M. (2006). Immunomodulatory vaccines against autoimmune diseases. Rejuvenation Research, Vol.9, No.1, pp. 126-133

Selgas, L., Arce, A., Esquifino, A.I., \& Cardinali, D.P. (1997). Twenty-four-hour rhythms of serum $\mathrm{ACTH}$, prolactin, growth hormone, and thyroid-stimulating hormone, and of median-eminence norepinephrine, dopamine, and serotonin, in rats injected with Freund's adjuvant. Chronobiology International, Vol.14, No.3, pp. 253-265

Sibley, W.A. (1997). Risks factors in multiple sclerosis, In: Multiple Sclerosis: Clinical and Pathogenic Basis, C.S. Raine, H.F. McFarland, W.W. Tourtellotte, (Eds), 141-148, Chapman and Hall, London

Sieve, A.N., Steelman, A.J., Young, C.R., Storts, R., Welsh, T.H., Welsh, C.J., \& Meagher, M.W. (2004). Chronic restraint stress during early Theiler's virus infection 
exacerbates the subsequent demyelinating disease in SJL mice. Journal of Neuroimmunology, Vol.155, No.1-2, pp. 103-118

Sieve, A.N., Steelman, A.J., Young, C.R., Storts, R., Welsh, T.H., Welsh, C.J., \& Meagher, M.W. (2006). Sex-dependent effects of chronic restraint stress during early Theiler's virus infection on the subsequent demyelinating disease in CBA mice. Journal of Neuroimmunology, Vol.177, No.1-2, pp. 46-62

Simas, J.P., \& Fazakerley, J.K. (1996). The course of disease and persistence of virus in the central nervous system varies between individual CBA mice infected with the BeAn strain of Theiler's murine encephalomyelitis virus. The Journal of General Virology, Vol.77, No.11, pp. 2701-2711

Solaro, C., \& Messmer Uccelli, M. (2010). Pharmacological management of pain in patients with multiple sclerosis. Drugs, Vol.70, No.10, pp. 1245-1254

Sommer, N., Löschmann, P.A., Northoff, G.H., Weller, M., Steinbrecher, A., Steinbach, J.P., Lichtenfels, R., Meyermann, R., Riethmüller, A., Fontana, A., Dichgans, J., \& Martin, R. (1995). The antidepressant rolipram suppresses cytokine production and prevents autoimmune encephalomyelitis. Nature Medicine, Vol.1, No.3, pp. 244-248

Sospedra, M., \& Martin, R. (2005). Immunology of multiple sclerosis. Annual Review of Immunology, Vol.23, pp. 683-747

Steelman, A.J., Dean, D.D., Young, C.R., Smith, R. 3rd., Prentice, T.W., Meagher, M.W., \& Welsh, C.J. (2009). Restraint stress modulates virus specific adaptive immunity during acute Theiler's virus infection. Brain, Behavior, and Immunity, Vol.23, No.6, pp. 830-843

Steelman, A.J., Alford, E., Young, C.R., Welsh, T.H., Meagher, M.W., \& Welsh, C.J. (2010). Restraint stress fails to render C57BL/ 6 mice susceptible to Theiler's virus-induced demyelination. Neuroimmunomodulation, Vol.17, No.2, pp. 109-119

Steinman, L., \& Zamvil, S.S. (2006). How to successfully apply animal studies in experimental allergic encephalomyelitis to research on multiple sclerosis. Annals of Neurology, Vol.60, No.1, pp. 12-21

Stoebner, P.E., Carayon, P., Casellas, P., Portier, M., Lavabre-Bertrand, T., Cuq, P., Cano, J.P., Meynadier, J., \& Meunier, L. (2001). Transient protection by peripheral benzodiazepine receptors during the early events of ultraviolet light-induced apoptosis. Cell Death and Differentiation, Vol.8, No.7, pp. 747-753

Stork, C.M., \& Hoffman, R.S. (1994). Characterization of 4-aminopyridine in overdose. Journal of Toxicology. Clinical Toxicology, Vol.32, No.5, pp. 583-587

Stüve, O., Youssef, S., Weber, M.S., Nessler, S., von Büdingen, H.C., Hemmer, B., Prod'homme, T., Sobel, R.A., Steinman, L., \& Zamvil, S.S. (2006). Immunomodulatory synergy by combination of atorvastatin and glatiramer acetate in treatment of CNS autoimmunity. The Journal of Clinical Investigation, Vol.116,No.4, pp. 1037-1044

Teunis, M.A., Heijnen, C.J., Sluyter, F., Bakker, J.M., Van Dam, A.M., Hof, M., Cools, A.R., \& Kavelaars, A. (2002). Maternal deprivation of rat pups increases clinical symptoms of experimental autoimmune encephalomyelitis at adult age. Journal of Neuroimmunology, Vol.133, No.1-2, pp. 30-38

Then Bergh, F., Kümpfel, T., Trenkwalder, C., Rupprecht, R., \& Holsboer, F. (1999). Dysregulation of the hypothalamo-pituitary-adrenal axis is related to the clinical course of MS. Neurology, Vol.53, No.4, pp. 772-777 
Tsunoda, I., \& Fujinami, R.S. (1996). Two models for multiple sclerosis: experimental allergic encephalomyelitis and Theiler's murine encephalomyelitis virus. Journal of Neuropathology and Experimental Neurology, Vol.55, No.6, pp. 673-686

Varela-Patiño, M.P., Núñez, M.J., Losada, C., Pereiro, D., Castro-Bolaño, C., Saburido, X.L., Otero, J.M., Mayán, J.M., Blanco, A., Rey-Méndez, M., \& Freire-Garabal, M. (1994). Effects of alprazolam on delayed type hypersensitivity (DTH) response in stressed mice. Research Communications in Psychology, Psychiatry and Behavior, Vol.19, No.1-2, pp. 69-77

Velez, L., Shirazi, F., Goto, C., Shepherd, G., \& Roth, B.A. (2003). Opisthotonic posturing with neuromuscular irritability attributable to 4-aminopyridine ingestion by a healthy pediatric patient. Pediatrics, Vol.111, No.1, pp. e82-84

Venneti, S., Lopresti, B.J., \& Wiley, C.A. (2006). The peripheral benzodiazepine receptor (Translocator protein $18 \mathrm{kDa}$ ) in microglia: from pathology to imaging. Progress in Neurobiology, Vol.80, No.6, pp. 308-322

Versijpt, J., Debruyne, J.C., Van Laere, K.J., De Vos, F., Keppens, J., Strijckmans, K., Achten, E., Slegers, G., Dierckx, R.A., Korf, J., \& De Reuck, J.L. (2005). Microglial imaging with positron emission tomography and atrophy measurements with magnetic resonance imaging in multiple sclerosis: a correlative study. Multiple Sclerosis, Vol.11, No.2, pp. 127-134

Vowinckel, E., Reutens, D., Becher, B., Verge, G., Evans, A., Owens, T., \& Antel, J.P. (1997). PK11195 binding to the peripheral benzodiazepine receptor as a marker of microglia activation in multiple sclerosis and experimental autoimmune encephalomyelitis. Journal of Neuroscience Research, Vol.50, No.2, pp. 345-353

Warren, S., Greenhill, S., \& Warren, K.G. (1982). Emotional stress and the development of multiple sclerosis: case-control evidence of a relationship. Journal of Chronic Diseases, Vol.35, No.11, pp. 821-831

Welsh, C.J., Tonks, P., Borrow, P., \& Nash, A.A. (1990). Theiler's virus: an experimental model of virus-induced demyelination. Autoimmunity, Vol.6, No.1-2, pp. 105-112

Welsh, C.J., Bustamante, L., Nayak, M., Welsh, T.H., Dean, D.D., \& Meagher, M.W. (2004). The effects of restraint stress on the neuropathogenesis of Theiler's virus infection II: NK cell function and cytokine levels in acute disease. Brain, Behavior, and Immunity, Vol.18, No.2, pp. 166-174

Welsh, C.J., Steelman, A.J., Mi, W., Young, C.R., Storts, R., Welsh, T.H. Jr., \& Meagher, M.W. (2009). Neuroimmune interactions in a model of multiple sclerosis. Annals of the New York Academy of Sciences, Vol.1153, No.1, pp. 209-219

Whitacre, C.C., Dowdell, K., \& Griffin, A.C. (1998). Neuroendocrine influences on experimental autoimmune encephalomyelitis. Annals of the New York Academy of Sciences, Vol.840, No.1, pp. 705-716

Whitacre, C.C., Reingold, S.C., \& O'Looney, P.A. (1999). A gender gap in autoimmunity. Science, Vol.283, No.5406, pp. 1277-1278

Wilms, H., Claasen, J., Röhl, C., Sievers, J., Deuschl, G., \& Lucius, R. (2003). Involvement of benzodiazepine receptors in neuroinflammatory and neurodegenerative diseases: evidence from activated microglial cells in vitro. Neurobiology of Disease, Vol.14, No.3, pp. 417-424 
Woodruff, R.H., \& Franklin, R.J. (1999). The expression of myelin protein mRNAs during remyelination of lysolecithin-induced demyelination. Neuropathology and Applied Neurobiology, Vol.25, No.3, pp. 226-235

Woods, M.J., \& Williams, D.C. (1996). Multiple forms and locations for the peripheral-type benzodiazepine receptor. Biochemical Pharmacology, Vol.52, No.12, pp. 1805-1814

Yerdelen, D., Karatas, M., Goksel, B., \& Yildirim, T. (2008). A patient with multiple sclerosis presenting with Holmes' tremor. European Journal of Neurology, Vol.15, No.1, pp. e23

Young, E.E., Prentice, T.W., Satterlee, D., McCullough, H., Sieve, A.N., Johnson, R.R., Welsh, T.H., Welsh, C.J., \& Meagher, M.W. (2008). Glucocorticoid exposure alters the pathogenesis of Theiler's murine encephalomyelitis virus during acute infection. Physiology \& Behavior, Vol.95, No.1-2, pp. 63-71

Young, E.E., Sieve, A.N., Vichaya, E.G., Carcoba, L.M., Young, C.R., Ambrus, A., Storts, R., Welsh, C.J., \& Meagher, M.W. (2010). Chronic restraint stress during early Theiler's virus infection exacerbates the subsequent demyelinating disease in SJL mice: II. CNS disease severity. Journal of Neuroimmunology, Vol.220, No.1-2, pp. 79-89

Zavala, F., \& Lenfant, M. (1987). Benzodiazepines and PK 11195 exert immunomodulating activities by binding on a specific receptor on macrophages. Annals of the New York Academy of Sciences, Vol.496, No.1, pp. 240-249

Zavala, F., Taupin, V., \& Descamps-Latscha, B. (1990). In vivo treatment with benzodiazepines inhibits murine phagocyte oxidative metabolism and production of interleukin 1, tumor necrosis factor and interleukin-6. The Journal of Pharmacology and Experimental Therapeutics, Vol.255, No.2, pp. 442-450 


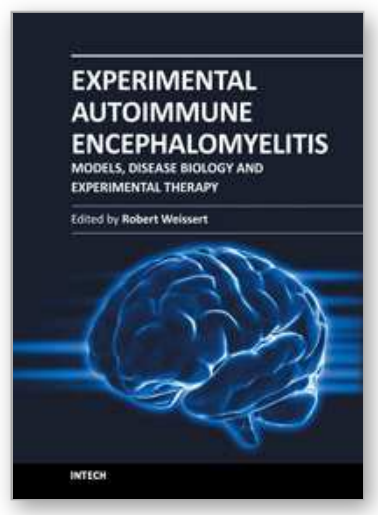

\author{
Experimental Autoimmune Encephalomyelitis - Models, Disease \\ Biology and Experimental Therapy \\ Edited by Prof. Robert Weissert
}

ISBN 978-953-51-0038-6

Hard cover, 162 pages

Publisher InTech

Published online 03, February, 2012

Published in print edition February, 2012

Experimental Autoimmune Encephalomyelitis - Models, Disease Biology and Experimental Therapy is totally focused on the model of multiple sclerosis, experimental autoimmune encephalomyelitis (EAE). The book chapters give a very good and in depth overview about the currently existing and most used EAE models. In addition, chapters dealing with novel experimental therapeutic approaches demonstrate the usefulness of the EAE model for MS research. With an international perspective, this book features contributions from authors throughout the world, Australia, Germany, Japan, Spain, Taiwan, and USA. There is an impressive international Faculty that provides insight into current research themes. This further demonstrates the importance of EAE in research all over the world. The book will provide established researchers and students with novel insights and guidance for their research and will help to push the field forward.

\title{
How to reference
}

In order to correctly reference this scholarly work, feel free to copy and paste the following:

Silvia Novío, Manuel Freire-Garabal and María Jesús Núñez-Iglesias (2012). Effects of Anxiolytic Drugs in Animal Models of Multiple Sclerosis, Experimental Autoimmune Encephalomyelitis - Models, Disease Biology and Experimental Therapy, Prof. Robert Weissert (Ed.), ISBN: 978-953-51-0038-6, InTech, Available from:

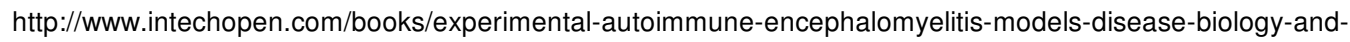
experimental-therapy/effects-of-ansiolitic-drugs-in-animal-models-of-multiple-sclerosis

\section{INTECH}

open science | open minds

\author{
InTech Europe \\ University Campus STeP Ri \\ Slavka Krautzeka 83/A \\ 51000 Rijeka, Croatia \\ Phone: +385 (51) 770447 \\ Fax: +385 (51) 686166 \\ www.intechopen.com
}

\author{
InTech China \\ Unit 405, Office Block, Hotel Equatorial Shanghai \\ No.65, Yan An Road (West), Shanghai, 200040, China \\ 中国上海市延安西路65号上海国际贵都大饭店办公楼 405 单元 \\ Phone: +86-21-62489820 \\ Fax: $+86-21-62489821$
}


(C) 2012 The Author(s). Licensee IntechOpen. This is an open access article distributed under the terms of the Creative Commons Attribution 3.0 License, which permits unrestricted use, distribution, and reproduction in any medium, provided the original work is properly cited. 